\title{
Photosynthetic parameters and growth of rice, lettuce, sunflower and tomato in an Entisol as affected by soil acidity and bioaccumulation of $\mathrm{Ba}, \mathrm{Cd}, \mathrm{Cu}, \mathrm{Ni}$ and $\mathrm{Zn}$
}

Flávio Henrique Silveira Rabêlo ( $\sim$ flaviohsr.agro@usp.br)

Universidade de São Paulo Escola Superior de Agricultura Luiz de Queiroz https://orcid.org/0000-0002-8804-7182

José Lavres

Universidade de São Paulo Centro de Energia Nuclear na Agricultura: Universidade de Sao Paulo Centro de Energia Nuclear na Agricultura

Flávio Pinto

ESALQ-USP: Universidade de Sao Paulo Escola Superior de Agricultura Luiz de Queiroz

Luís Alleoni

ESALQ-USP: Universidade de Sao Paulo Escola Superior de Agricultura Luiz de Queiroz

\section{Research Article}

Keywords: Food safety, Human health, Metals translocation, Soil chemistry, Trace elements uptake

Posted Date: February 11th, 2021

DOI: https://doi.org/10.21203/rs.3.rs-224497/v1

License: (1) This work is licensed under a Creative Commons Attribution 4.0 International License. Read Full License 


\section{Abstract}

The bioaccumulation of trace elements (TEs) in crops consumed by humans can lead to a lower food production due to photosynthetic damages and several diseases in humans, but decreasing soil acidity could mitigate these problems by decreasing TEs bioavailability. Thus, we evaluate the effect of increasing soil base saturation (BS\%) on photosynthesis, growth and bioaccumulation of barium (Ba), cadmium (Cd), copper (Cu), nickel (Ni) or zinc ( $\mathrm{Zn}$ ) in lettuce (Lactuca sativa L.), rice (Oryza sativa L.), sunflower (Helianthus annuus L.) and tomato (Solanum lycopersicum L.) grown in sandy Entisol. The crops were grown in uncontaminated or contaminated Entisol, under two BS\% ratios: $30 \%$ for all crops or $50 \%$ for rice and $70 \%$ for lettuce, sunflower and tomato. The photosynthesis-related parameters varied depending on the metal and crop, but in general, increasing BS\% did not attenuate photosynthetic damages induced by $\mathrm{Ba}, \mathrm{Cd}, \mathrm{Cu}, \mathrm{Ni}$ and $\mathrm{Zn}$ in the crops. There was no strong correlation between the photosynthetic parameters measured and biomass production, which suggest us that the suppression on biomass induced by $\mathrm{Ba}, \mathrm{Cd}, \mathrm{Cu}, \mathrm{Ni}$ or $\mathrm{Zn}$ is related to other metabolic disorders besides the impairment on $\mathrm{CO}_{2}$ assimilation or chlorophyll synthesis in the crops assayed, with exception of $\mathrm{Ni}$ and $\mathrm{Zn}$ in lettuce. In conclusion, increasing BS\% was not consistent in decreasing $\mathrm{Ba}, \mathrm{Cd}, \mathrm{Cu}, \mathrm{Ni}$ and $\mathrm{Zn}$ accumulation in the edible parts of lettuce, rice, sunflower and tomato grown in the sandy soil, which probably is related to the low capacity of this soil in control TEs bioavailability.

\section{Introduction}

Trace elements (TEs) are minor components of the solid soil phase, but they play an important role in soil fertility, soil contamination and food production (Gupta et al. 2019). Although soil composition is diverse, elements such as barium (Ba), cadmium (Cd), copper (Cu), nickel (Ni) and zinc (Zn) are commonly present in low concentrations (Kabata-Pendias 2011). In the State of São Paulo - Brazil, concentrations of $54.1,0.1,24.2,36.0$ and $21.8 \mathrm{mg} \mathrm{kg}^{1}$ have been reported for $\mathrm{Ba}, \mathrm{Cd}, \mathrm{Cu}, \mathrm{Ni}$ and $\mathrm{Zn}$, respectively, in unpolluted soils (Cardoso-Silva et al. 2016; Nogueira et al. 2018). However, the increasing soil contamination with these elements through anthropogenic activities, like mining, have become a global issue and environmental threat because these TEs can be accumulated in plant tissues and enter into food chain (Jolly et al. 2013).

Crops such as lettuce (Lactuca sativa L.), rice (Oryza sativa L.), sunflower (Helianthus annuus L.) and tomato (Solanum lycopersicum L.) are between the most consumed food in the world, and these crops can accumulate TEs in their edible parts in concentrations enough to cause clinical problems to humans (Piotto et al. 2018; Gupta et al. 2019; Lavres et al. 2011, 2019). Nervous, cardiovascular, renal, and neurological impairment as well as bone diseases caused by TEs have been reported in humans (Tchounwou et al. 2012; Petrosino et al. 2018). In this sense, the employment of strategies that mitigate TEs uptake by crops is quite important to decrease their intake.

Plants can take up only bioavailable TEs from the soil, and this process depends on uptake mechanisms, physicochemical properties of the soil and chemical speciation of the metals and metalloids in the soils (Gupta et al. 2019). Thus, agricultural practices that influence TEs bioavailability often have an impact on their accumulation in plants. Lime is often used to correct soil acidity and allow an adequate crops' development (Raij et al. 1996). Higher pH tends to increase sorption and decrease the bioavailability and mobility of most TEs in tropical soils (Rieuwerts 2007). Macedo et al. (2020) evaluated the effect of two base saturation (BS ratios of 50 and $70 \%$ ) on sunflower and soybean growth in an Alfisol and observed that Ni bioavailability was lower and the biomass production was higher at soil base saturation of $70 \%$ compared to $50 \%$. Although TEs such as $\mathrm{Cu}, \mathrm{Ni}$ and $\mathrm{Zn}$ are essential (micronutrients) at low concentrations for plant growth (Hänsch and Mendel 2009), they also can cause toxic effects on plant growth at high concentrations, as well as Ba and Cd that are non-essential for plants.

Physiological effects of TEs toxicity in plants include reductions on biomass, changes on photosynthetic efficiency and transpiration (Gupta et al. 2019). Changes on chlorophyll synthesis and starch accumulation have been reported also in plants exposed to many TEs (Moya et al. 1993; Piotto et al. 2018; Lavres et al. 2019). In this sense, a lower TEs uptake and translocation is desirable to avoid photosynthetic damages and to decrease TEs intake by humans.

The differences observed in TEs' accumulation among crops depends on the TEs' bioavailability, efficiency of a plant species in accumulating TEs into its tissues from the soil, TEs' translocation from roots to shoot and further from leaves and stems to fruits or grains (Antoniadis et al. 2017). Li et al. (2019) measured, through bioconcentration factor (BCF) and translocation factor (TF), Cd transfer from soils to rice plants in China, and reported that $\mathrm{Cd}$ translocation to the grains of rice plants grown in soils that presented higher $\mathrm{pH}$ values (which correspond to higher base saturation) was lower. According to Li et al. (2019), soil properties were highly relevant for Cd accumulation in rice plants.

Increasing soil base saturation through liming is an important strategy to decrease TEs bioavailability in soils presenting low organic carbon (OC) and clay contents, and low cationic exchange capacity (CEC), such as sandy soils (Rieuwerts 2007). To the best of our 
knowledge there is no available information on TEs transfer from soil to edible parts of crops grow in Entisols. Thus, our aims with this study were to evaluate: i) the effect of base saturation on changes induced by TEs on chlorophyll concentration, leaf $\mathrm{CO}_{2}$ assimilation, stomatal conductance, intracellular $\mathrm{CO}_{2}$ concentration and transpiration, and growth of lettuce, rice, sunflower and tomato grown in $\mathrm{Ba}$, $\mathrm{Cd}$, $\mathrm{Cu}, \mathrm{Ni}$ or $\mathrm{Zn}$-contaminated Entisol; and ii) the uptake and root-to-shoot translocation of $\mathrm{Ba}, \mathrm{Cd}, \mathrm{Cu}, \mathrm{Ni}$ and $\mathrm{Zn}$ and in the crops.

\section{Material And Methods Soil characterization}

The soil (Typic Quatzipsamment) used in this study was collected from the upper layer (0.0-0.2 m depth), apart from litter, in São Pedro, state of São Paulo, Brazil (22 $32^{\prime} \mathrm{S} ; 47^{\circ} 54^{\prime} \mathrm{W}$ ). Soil characteristics were determined on air-dried soil sieved with a 2-mm mesh (Table 1), following the procedures described by Nelson and Sommer (1982) to determine OC content, after digestion with $\mathrm{K}_{2} \mathrm{Cr}_{2} \mathrm{O}_{7}$ and $\mathrm{H}_{2} \mathrm{SO}_{4}$. Exchangeable aluminum $\left(\mathrm{Al}^{3+}\right)$ was extracted with $1 \mathrm{~mol} \mathrm{~L}^{-1} \mathrm{KCl}$ and determined by titration with $0.025 \mathrm{~mol} \mathrm{~L}^{-1} \mathrm{NaOH}$ (Raij et al. 2001). The $\mathrm{pH}$ was determined firstly in $0.01 \mathrm{~mol} \mathrm{~L}^{-1} \mathrm{CaCl}_{2}$ and then in SMP solution to estimate the potential acidity (H+Al) (Raij et al. 2001). The available concentrations of $\mathrm{Ca}, \mathrm{Mg}, \mathrm{K}$ and $\mathrm{P}$ were extracted with ionic exchange resin (Raij et al. 1986).

From these results we calculated then the sum of bases $(\mathrm{SB})$, total cationic exchange capacity $\left(\mathrm{CEC}_{7}\right)$, base saturation ( $\mathrm{BS} \%$ ), and $\mathrm{Al}^{3+}$ saturation ( $\mathrm{m} \%$ ) (EMBRAPA 1997). The pseudo-total $\mathrm{Ba}, \mathrm{Cd}, \mathrm{Cu}, \mathrm{Ni}$, and $\mathrm{Zn}$ concentrations were determined using the method 3051A (digestion in a closed microwave oven system with concentrated $\mathrm{HNO}_{3}$ and $\mathrm{HCl}$ (3:1) proposed by United States Environmental Protection Agency - USEPA (USEPA 2007). Granulometric fractions (sand, silt and clay) were obtained by the hydrometer method (Gee and Bauder 2002).

\section{Plant material and experimental design}

To assay the effect of base saturation on plant growth and $\mathrm{Ba}, \mathrm{Cd}, \mathrm{Cu}, \mathrm{Ni}$ and $\mathrm{Zn}$ uptake by crops ingested by humans, plants of lettuce (cv. Amanda), rice (cv. IAC-202), sunflower (cv. Aguará 4), and tomato (cv. Santa Clara VF 5600) were grown in greenhouse conditions in unpolluted (control treatment) or polluted Entisol, under two base saturation (30\% for all crops or $50 \%$ for rice and $70 \%$ for lettuce, sunflower and tomato). The original base saturation of the Entisol (Table 1) was increased to $30 \%$ for all crops or to $50 \%$ for rice and $70 \%$ for lettuce, sunflower and tomato (optimum recommended to growth the crops assayed), following the recommendations for Brazil (Raij et al. 1996). The Entisol was polluted individually with Ba $\left(120 \mathrm{mg} \mathrm{kg}^{-1}\right), \mathrm{Cd}\left(1.3 \mathrm{mg} \mathrm{kg}^{-1}\right), \mathrm{Cu}\left(60 \mathrm{mg} \mathrm{kg}^{-1}\right), \mathrm{Ni}\left(30 \mathrm{mg} \mathrm{kg}^{-1}\right)$ or Zn $\left(86 \mathrm{mg} \mathrm{kg} \mathrm{Zn}^{-1} \mathrm{Zn}\right.$. These concentrations correspond to the prevention levels established by The Environmental Agency of São Paulo State - CETESB, in Brazil (CETESB 2014). According to CETESB (2014), prevention level is the concentration of the substance (e.g., TEs) above which harmful changes to soil and groundwater quality can occur. The pots used to grow the crops were distributed in completely randomized design with three replicates per condition.

\section{Soil treatment, growth conditions, plant harvesting and sampling}

After collection, drying and soil characterization, the base saturation of the Entisol was increased to the desirable values ( $30 \%$ for all crops or $50 \%$ for rice and $70 \%$ for lettuce, sunflower and tomato) by using $\mathrm{MgCO}_{3}$ and $\mathrm{CaCO}_{3}$. Then, $6 \mathrm{~kg}$ of soil for lettuce and rice and $10 \mathrm{~kg}$ of soil for sunflower and tomato were arranged in plastic pots that received deionized water until the soil reach $95 \%$ of their maximum water holding capacity.

The soil was incubated in this condition for 21 days, at maximum temperature of $31^{\circ} \mathrm{C}$. After this incubation period, $\mathrm{Ba}, \mathrm{Cd}, \mathrm{Cu}, \mathrm{Ni}$ or $\mathrm{Zn}$ solutions were added in the following concentrations: $120 \mathrm{mg} \mathrm{Ba} \mathrm{kg}^{-1}\left[\mathrm{Ba}\left(\mathrm{NO}_{3}\right)_{2}\right], 1.3 \mathrm{mg} \mathrm{Cd} \mathrm{kg}^{-1}\left[\mathrm{Cd}\left(\mathrm{NO}_{3}\right)_{2} \cdot 4 \mathrm{H}_{2} \mathrm{O}\right], 60 \mathrm{mg} \mathrm{Cu} \mathrm{kg}^{-1}$ $\left[\mathrm{Cu}\left(\mathrm{NO}_{3}\right)_{2} \cdot 3 \mathrm{H}_{2} \mathrm{O}\right], 30 \mathrm{mg} \mathrm{Ni} \mathrm{kg}^{-1}\left[\mathrm{Ni}\left(\mathrm{NO}_{3}\right)_{2} \cdot 6 \mathrm{H}_{2} \mathrm{O}\right]$ and $86 \mathrm{mg} \mathrm{Zn} \mathrm{kg}^{-1}\left[\mathrm{Zn}\left(\mathrm{NO}_{3}\right)_{2} \cdot 6 \mathrm{H}_{2} \mathrm{O}\right]$. Variations on $\mathrm{N}$ supply were corrected by using $\mathrm{NH}_{4} \mathrm{NO}_{3}$, including the unpolluted Entisol (control treatment), and then, the soil was incubated again for seven days at $95 \%$ of their maximum water holding capacity.

After soil incubation, lettuce and tomato seedlings germinated in vermiculite were transferred to their pots at 29 and 34 days after sowing, respectively, whilst rice and sunflower were sown directly in the pots. One plant of sunflower and tomato was kept per pot after thinning, whilst three plants of lettuce and five plants of rice were kept per pot. Soil moisture content was maintained at a constant level $(70 \%$ of the maximum water holding capacity) during the study, with deionized water.

The basic fertilization was performed applying $90 \mathrm{mg} \mathrm{N} \mathrm{kg}^{-1}, 200 \mathrm{mg} \mathrm{P} \mathrm{kg}^{-1}, 50 \mathrm{mg} \mathrm{K} \mathrm{kg}^{-1}, 23.2 \mathrm{mg} \mathrm{S} \mathrm{kg}^{-1}, 1 \mathrm{mg} \mathrm{B} \mathrm{kg}^{-1}, 5 \mathrm{mg} \mathrm{Cl} \mathrm{kg}^{-1}, 1 \mathrm{mg} \mathrm{Cu}$ $\mathrm{kg}^{-1}, 5 \mathrm{mg} \mathrm{Mn} \mathrm{kg}^{-1}$ and $3 \mathrm{mg} \mathrm{Zn} \mathrm{kg}^{-1}$ (Cu and Zn were not applied in the Cu and Zn-polluted soils), following the recommendations of Raij et 
al. (1996). Fifteen days after lettuce, sunflower and tomato sowing, and 20 days after rice sowing, $50 \mathrm{mg} \mathrm{K} \mathrm{kg}^{-1}$ and $20.5 \mathrm{mg} \mathrm{S} \mathrm{kg}^{-1}$ were applied on the top. A new fertilization on the top with $50 \mathrm{mg} \mathrm{N} \mathrm{kg}^{-1}$ and $50 \mathrm{mg} \mathrm{K} \mathrm{kg}^{-1}$ was performed at 48 days after rice, sunflower and tomato sowing (Raij et al. 1996).

To control the caterpillar pest known as "cabbage looper" (Trichoplusia $n i$ ) that was found in the leaves of all crops during the study, 28.2 $\mathrm{mL} \mathrm{ha}^{-1}$ of thiamethoxam and $21.2 \mathrm{~mL} \mathrm{ha}^{-1}$ of lambda-cyhalothrin were applied after the first top fertilization. It was also necessary to control the powdery mildew (Microsphaera diffusa) in rice and sunflower plants, which was done through two applications of $250 \mathrm{~g}$ ha ${ }^{-1}$ of carbendazim in their leaves (the first application occurred after the first top fertilization, and the second application was performed after the second top fertilization).

Plants of lettuce were harvested at 42 days after transplanting (end of vegetative phase), while rice was harvested at 98 days after sowing (phenological reproductive stage R8), sunflower was harvested at 82 days after sowing (phenological reproductive stage R9), and tomato was harvested at 68 days after transplanting (after the harvesting of mature fruits). Plants were harvested and separated into roots, shoot and fruits or grains (except for lettuce that was separated only into roots and shoot). The plant material collected was dried in a forced ventilation oven at $45^{\circ} \mathrm{C}$ until reach constant weight to determine the biomass production. The soil collected at the end of the study was sieved (2-mm mesh) and dried in a forced ventilation oven at $45^{\circ} \mathrm{C}$ to determine the pseudo-total $\mathrm{Ba}, \mathrm{Cd}, \mathrm{Cu}, \mathrm{Ni}$ and $\mathrm{Zn}$ concentrations.

\section{Determination of the pseudo-total $\mathrm{Ba}, \mathrm{Cd}, \mathrm{Cu}, \mathrm{Ni}$ and $\mathrm{Zn}$ concentrations in the Entisol}

Pseudo-total concentrations were determined in triplicate after a microwave-assisted (Model TC plus labstation, Milestone, Sorisole, Italy) according to the USEPA 3051A method (USEPA, 2007). Extracts were analyzed by inductively coupled plasma optical emission spectroscopy (ICP-OES, iCAP 7000 SERIES, Thermo Fisher Scientific, Waltham, USA). Blank reagent samples and standard reference material (SRM 2709a - San Joaquin soil) were used during digestion for quality control.

\section{Determination of $\mathrm{Ba}, \mathrm{Cd}, \mathrm{Cu}, \mathrm{Ni}$ and $\mathrm{Zn}$ concentrations and contents in the plant material}

After drying in an oven at $45^{\circ} \mathrm{C}$ until reach constant weight, the plant material was ground in a Wiley type mill (Model 4 , Thomas Scientific, Swedesboro, USA) and digested in a microwave (Model TC plus labstation, Milestone) oven using a mixture of $\mathrm{HNO}_{3}+\mathrm{H}_{2} \mathrm{O}_{2}$, following the USEPA 3051A method (USEPA 2007) for TEs determination by inductively coupled plasma optical emission spectrometry (ICP-OES, iCAP 7000 SERIES, Thermo Fisher Scientific).

Blank reagent samples were used in the digestion for quality control. Standard reference material (SRM1515 - apple leaves) was also used to assure the accuracy and precision of the analytical methods. Then, from the TEs concentrations we calculated the TEs content by multiplying the TE concentration in the tissue (roots, shoot and grains or fruits) by the dry weight of the respective tissue. Subsequently, the TE content in each tissue was added, resulting in the total TE content (roots + shoot + grains or fruits).

\section{Calculation of BCF and TF for $\mathrm{Ba}, \mathrm{Cd}, \mathrm{Cu}, \mathrm{Ni}$ and $\mathrm{Zn}$}

The transfer of TEs in the crops tissues was evaluated by two indicators (Antoniadis et al. 2017): i) the bioconcentration factor (BCF), which indicates the efficiency of a plant species in accumulating a TE into its tissues from the soil (Eq. 1), and ii) the translocation factor (TF), which indicates the plant capacity to translocate TEs from roots to aboveground parts (Eq. 2):

$\mathrm{BCF}=\left[\mathrm{TE}_{\mathrm{crop}}\right] /\left[\mathrm{TE}_{\mathrm{soil}}\right](1)$

where: [TE $\mathrm{Crop}]\left(\mathrm{mg} \mathrm{kg}^{-1} \mathrm{DW}\right)$ is the TE concentration in the roots, shoot and grains or fruits of the plants, and [TE $\left.\mathrm{soi}\right]$ ( $\left.\mathrm{mg} \mathrm{kg}^{-1} \mathrm{soil}\right)$ is the pseudo-total TE concentration in the soil.

$\mathrm{TF}=\left[\mathrm{TE}_{\text {shoot }}\right] /\left[\mathrm{TE}_{\text {roots }}\right](2)$

where: $\left[\mathrm{TE}_{\text {shoot }}\right]\left(\mathrm{mg} \mathrm{kg}^{-1} \mathrm{DW}\right)$ is the TE concentration in the shoot (stem + leaves + grains or fruits), and [TE $\left.\mathrm{Foots}\right]\left(\mathrm{mg} \mathrm{kg}^{-1} \mathrm{DW}\right)$ is the TE concentration in the roots.

\section{Determination of the photosynthetic parameters in the crops assayed}

Leaf area was determined in a leaf area integrator model LI 3100 (Li-Cor Inc., Lincoln, USA) in the moment of the plant harvest. Chlorophyll concentration was measured during the vegetative phase (at 17 and 18 days after lettuce and tomato transplanting, respectively, and at 14 days after rice and sunflower emergence) by a Chlorophyll Meter SPAD-502 (Soil-Plant Analysis Dev., Section, Minolta Camera Co., Osaka, 
Japan). Chlorophyll concentrations as well as the following photosynthetic parameters were measured in the first fully expanded leaf of lettuce and rice, and in the second pair of leaves from above to the top of sunflower and tomato.

Photosynthetic parameters [leaf $\mathrm{CO}_{2}$ assimilation $(A)$, stomatal conductance $\left(g_{s}\right)$, intracellular $\mathrm{CO}_{2}$ concentration $\left(C_{i}\right)$ and transpiration $(E)$ ] were measured using infrared gas analyzer ( $\mathrm{Li}-6400$, Li-cor Inc.) before the plant harvest. The parameters were measured at air $\mathrm{CO}_{2}$ concentration of $350 \mu \mathrm{mol} \mathrm{mol}^{-1}$ with photosynthetic photon flux density of $1000 \mu \mathrm{mol} \mathrm{m}^{-2} \mathrm{~s}^{-1}$ for lettuce and rice and $2000 \mu \mathrm{mol} \mathrm{m} \mathrm{m}^{-2} \mathrm{~s}^{-1} \mathrm{for}$ sunflower. All measurements were performed following the recommendations of Long and Bernacchi (2003). These photosynthetic measurements described (except for chlorophyll concentration) were not performed in tomato plants due to the beginning of the leaf senescence process in the moment of the plant harvest.

\section{Statistical analyses}

Both normality and homoscedasticity were checked. Then, all data were submitted to analysis of variance $(F$ test) and post-hoc Tukey test $(P \leq 0.05)$ through the Statistical Analysis System v. 9.2 (SAS Institute 2008). The graphs were constructed and plotted with SigmaPlot v. 10.0 (Systat Software Inc., San Jose, CA, USA). Results were expressed as mean \pm standard error of the mean.

\section{Results}

\section{Effect of base saturation on pseudo-total $\mathrm{Ba}, \mathrm{Cd}, \mathrm{Cu}, \mathrm{Ni}$ and $\mathrm{Zn}$ concentrations in the Entisol}

In general, there was no effect of soil base saturation on pseudo-total $\mathrm{Ba}, \mathrm{Cd}, \mathrm{Cu}, \mathrm{Ni}$ and $\mathrm{Zn}$ concentrations in the polluted Entisol, with few exceptions (Fig. 1). The pseudo-total Ba concentration in the Entisol cultivated with lettuce was $20 \%$ lower at base saturation of $70 \%$ compared to $30 \%$ (Fig. 1A). The increase on base saturation resulted also in a reduction of $28 \%$ in the pseudo-total Cu concentration in the Entisol cultivated with rice (Fig. 1C). On the other hand, there was an increase of 13 and $14 \%$ on the pseudo-total Cd concentration in the Entisol cultivated with rice and sunflower, respectively, when the soil base saturation was augmented (Fig. 1B).

The same occurred for the pseudo-total Zn concentration that was 55 and $23 \%$ higher in the Entisol cultivated with rice and sunflower, respectively, at the highest soil base saturation (Fig. 1E). However, in general, $\mathrm{Ba}, \mathrm{Cd}, \mathrm{Cu}, \mathrm{Ni}$ and $\mathrm{Zn}$ bioavailability decreased due to the increase on soil base saturation (results not shown). Details about the TEs bioavailability can be found in Pinto and Alleoni (2018).

\section{Effect of soil base saturation and $\mathrm{Ba}, \mathrm{Cd}, \mathrm{Cu}, \mathrm{Ni}$ and $\mathrm{Zn}$ exposure on biomass and photosynthesis}

Lettuce plants had higher shoot biomass when grown at base saturation of $70 \%$, regardless of TEs exposure (Fig. 2B). However, there was no effect of soil base saturation on root biomass, except for lettuce plants grown on Cu-polluted Entisol that presented higher root biomass at soil base saturation of $70 \%$ (Fig. 2C). Lettuce plants grown at base saturation of $30 \%$ were more susceptible to $\mathrm{Cu}, \mathrm{Ni}$ and $\mathrm{Zn}$ toxicity, but the increase on soil base saturation to $70 \%$ decreased the toxicity Cu-induced compared to the other TEs (Figs. 2B-C).

There was a positive effect of increasing soil base saturation on rice grains' production only for plants exposed to Cd or Zn (Fig. 2D). Meanwhile, rice growth and grains' production were more compromised by the toxicity Cu-induced compared to the other TEs (Figs. 2D-F). In general, sunflower plants grown at soil base saturation of $70 \%$ presented higher grains production (Fig. 2G), shoot (Fig. 2H) and root biomass (Fig. 2l) compared to plants grown at base saturation of $30 \%$. Sunflower was more susceptible to toxicity induced by $\mathrm{Ni}$ and $\mathrm{Zn}$ compared to the other TEs, especially when the plants were grown at the lowest base saturation (Figs. 2G-I).

There was no effect of base saturation on tomato fruits production, with exception for plants exposed to Ni that had higher fruits' production at base saturation of $70 \%$ (Fig. 2J). On the other hand, shoot and root biomass of tomato plants exposed to all TEs was higher at soil base saturation of 70\% (Figs. 2K-L). Tomato plants were more susceptible to Ni-induced toxicity, followed by $\mathrm{Cd}$, $\mathrm{Cu}$ and $\mathrm{Zn}$, especially when grown at BS of $30 \%$ (Figs. $2 \mathrm{~J}-\mathrm{L}$ ).

Besides to biomass decrease, TEs can induce several damages to photosynthesis-related parameters of plants. Lettuce was more susceptible to inhibition Cu-induced on leaf area and transpiration when grown at base saturation of $30 \%$ compared to $70 \%$ (Table 2 ). However, $\mathrm{Cd}, \mathrm{Ni}$ and $\mathrm{Zn}$ exposure decreased much more chlorophyll concentration of lettuce compared to $\mathrm{Cu}$, regardless of base saturation. The leaf $\mathrm{CO}_{2}$ assimilation and stomatal conductance in lettuce was compromised specially by $\mathrm{Ni}$ and $\mathrm{Zn}$, regardless of base saturation.

In general, there was no effect of base saturation on photosynthetic parameters measured in rice, as well as there was no great changes induced by the different TEs on leaf area, chlorophyll concentration, stomatal conductance, intracellular $\mathrm{CO}_{2}$ concentration and transpiration of rice grown at base saturation of $50 \%$ (Table 2). Nevertheless, there was inhibition Ni-induced on leaf $\mathrm{CO}_{2}$ assimilation of rice grown at base saturation of 50\%. There was increase on chlorophyll concentration and transpiration induced by the higher soil base

Page 5/18 
saturation in sunflower exposed to $\mathrm{Zn}$, which was also observed for leaf $\mathrm{CO}_{2}$ assimilation, stomatal conductance, intracellular $\mathrm{CO}_{2}$ concentration and transpiration of sunflower exposed to Ba. Despite the biomass of sunflower had been decreased by Ni and Zn (Figs. 2GI), these TEs did not induce severe photosynthetic damages, which suggest us that Ni and Zn toxicity in sunflower is related with other processes. Chlorophyll concentration in tomato was not affected by base saturation or TEs exposure.

\section{Effect of base saturation on uptake and transfer of $\mathrm{Ba}, \mathrm{Cd}, \mathrm{Cu}, \mathrm{Ni}$ and $\mathrm{Zn}$ to edible parts of crops}

The concentrations of the TEs in the edible parts of lettuce, rice, sunflower and tomato grown on unpolluted Entisol remained below of the maximum permitted levels by International Organizations, regardless of base saturation (data not shown). The Food and Agriculture Organization of the United Nations (FAO) for the World Health Organization (WHO) have established threshold values of 0.2 mg kg-1 DW for Cd, $40 \mathrm{mg} \mathrm{kg}^{-1}$ DW for Cu and $60 \mathrm{mg} \mathrm{kg}^{-1}$ DW for Zn (FAO and WHO 2011). In the case of Ba and Ni, nor FAO and WHO have established threshold values, but the Environmental Protection Agency's Integrated Risk Information System (EPA-IRIS) has established 0.3 mg kg ${ }^{-1}$ DW for Ba and Ni (EPA-IRIS 1987a,b). Thus, from this point, our focusing was directed to understand the effect of base saturation on uptake and translocation of $\mathrm{Ba}, \mathrm{Cd}, \mathrm{Cu}, \mathrm{Ni}$ and $\mathrm{Zn}$ in the crops grown in the polluted Entisol (Figs. 3 and 4). Barium, Cd and Ni concentrations recorded in the edible parts of all crops grown on polluted Entisol exceeded the maximum permitted levels described (Figs. 3A-B, 3E-F and 3M-N). Only lettuce grown on Cu-polluted Entisol at base saturation of $30 \%$ exceeded the maximum permitted levels for Cu in its edible part (Figs. 3l-J). Zinc concentration in the edible parts of lettuce and sunflower grown on Zn-polluted Entisol also exceeded the maximum permitted levels for Zn (FAO and WHO 2011), regardless of base saturation (Figs. 3Q-R).

Although lettuce had presented shoot's Cu concentration below of the maximum permitted levels for Cu when grown in the Cu-polluted Entisol at base soil saturation of $70 \%$, there was no significant effect of base saturation on $\mathrm{Ba}, \mathrm{Cd}, \mathrm{Cu}, \mathrm{Ni}$ and $\mathrm{Zn}$ concentrations in its shoot or roots (Figs. 3A-C, 3E-G, 3I-K, 3M-O and 3Q-S). There was also no effect of base saturation on $\mathrm{Ba}, \mathrm{Cd}, \mathrm{Cu}$ and $\mathrm{Ni}$ concentrations in the grains, shoot or roots of rice plants (Figs. 3A-C, 3E-G, 3I-K and 3M-O). However, Zn concentrations in the grains and roots of rice were lower at base saturation of $50 \%$ compared to $30 \%$ (Figs. $3 Q$ and $3 S$ ).

In general, sunflower tissues had higher Ba concentrations and lower Zn concentrations when this plant was grown at the highest base saturation (Figs. 3B-C and 3Q-R). There was no effect of soil base saturation on Cd, Cu and Ni concentrations in the grains, shoot or roots of sunflower plants (Figs. 3E-G, 3I-K and 3Q-S). Tomato plants grown at base saturation of 70\% presented lower Ba and $\mathrm{Zn}$ concentrations in its roots (Figs. $3 \mathrm{C}$ and $3 \mathrm{~S}$ ). Meanwhile, there was no effect of soil base saturation on $\mathrm{Cd}$, Cu and Ni concentrations in the fruits, shoot or roots of tomato (Figs. 3E-G, 3I-K and 3Q-S).

Sunflower plants presented higher Ba (Fig. 3A), Cd (Fig. 3E), Cu (Fig. 3I), Ni (Fig. 3M) and Zn (Fig. 3Q) concentrations in their grains compared to rice grains and tomato fruits, when the plants were grown at the highest base saturation. On the other hand, lettuce had higher $\mathrm{Ni}$ (Fig. 3N) and Zn (Fig. 3R) concentrations in its leaves compared to the other crops grown at the highest base saturation.

Higher TEs concentrations were found in the roots for all crops, followed by shoot and grains or fruits, respectively (Fig. 3). There was no effect of base saturation on Cd (Fig. 3H), Cu (Fig. 3L) and Ni (Fig. 3P) contents. However, sunflower and rice presented higher Ba content (Fig. 3D), whilst lettuce, sunflower and tomato presented higher Zn content (Fig. 3T) at the highest soil base saturation compared to 30\%, which can be attributed to the higher biomass production at the highest soil base saturation. Taking the TEs contents (Figs. 3D, 3H, 3L, 3P and $3 \mathrm{~T}$ ) into account, the crops assayed absorbed TEs from the polluted Entisol in the following order: lettuce, $\mathrm{Ba}=\mathrm{Zn}>\mathrm{Cu}=\mathrm{Ni}>\mathrm{Cd}$; rice, $\mathrm{Zn}>\mathrm{Ba}>\mathrm{Ni}>\mathrm{Cu}>\mathrm{Cd}$; sunflower, $\mathrm{Ba}>\mathrm{Zn}>\mathrm{Cu}>\mathrm{Ni}>\mathrm{Cd}$; and tomato, $\mathrm{Ba}=\mathrm{Zn}>\mathrm{Ni}>\mathrm{Cu}>\mathrm{Cd}$.

The higher TEs concentrations observed in the roots compared to shoot and grains or fruits (Fig. 3) were directly associated with the BCF and TF values recorded in this study (Fig. 4). All crops presented higher BCF in the roots, followed by shoot and grains or fruits, respectively (Figs. 4A-C, 4E-G, 4I-K, 4M-O and 4Q-S). There was effect of base saturation on BCF and TF values only in few cases. Lettuce plants grown at soil base saturation of $70 \%$ presented lower $\mathrm{BCF}$ for $\mathrm{Cd}$ and $\mathrm{Ni}$ in its shoot compared to soil base saturation of $30 \%$ (Figs. $4 \mathrm{~F}$ and $4 \mathrm{~N}$ ). The lower Ni BCF in the shoot was close related to the lower Ni TF observed in lettuce grown at base saturation of $70 \%$ (Fig. 4P).

Increasing soil base saturation to grow rice resulted in lower Zn BCF in the whole plant (Figs. 4Q-S) in relation to base saturation of 30\%, but oppositely there was an increase on Zn TF (Fig. 4T). Sunflower plants grown at the highest base saturation had lower Cd BCF in their shoots (Fig. 4F) and Zn BCF in their shoots and roots (Figs. 4R-S) in relation to plants grown at the lowest base saturation. In the same way, increasing soil base saturation resulted in lower TEs BCF in tomato. There was lower Ba BCF in the roots (Fig. 4C) and lower Ni BCF in the fruits and shoot (Figs. 4M-N) of tomato plants grown at base saturation of $70 \%$.

Cadmium can easily reach edible parts of the crops assayed compared to the other TEs (Figs. 4A-C, 4E-G, 4I-K, 4M-O and 4Q-S). There was a strong restriction on $\mathrm{Ba}$ and $\mathrm{Cu}$ long distance-translocation from roots to edible parts of all crops (Figs. 4A-C and 4I-K), which was

Page 6/18 
evidencing by the low Ba and Cu TFs (Figs. 4D and 4L). In general, lettuce, sunflower and tomato presented lower capacity to restrict Ba, Cd, $\mathrm{Cu}, \mathrm{Ni}$ and $\mathrm{Zn}$ concentration in their tissues than rice (Fig. 4).

There was not a clear relationship between BCF and TF values (Fig. 4), which indicates that besides TEs bioavailability, mechanisms involved on TEs uptake and translocation affected TEs concentration in the edible parts of the crops assayed. Comparatively, sunflower and tomato plants had higher $\mathrm{Cd}$ and lower $\mathrm{Zn}$ translocation, respectively, in relation to lettuce and rice (Figs. 4H and 4T). Tomato presented high capacity for Ni translocation, as well as lettuce (Fig. 4P). In summary, our results suggest that increasing base saturation tends to decrease TEs BCF, but this process strongly depends on physiological mechanisms of the crops involved on TEs uptake and translocation.

\section{Discussion}

There is a great variation among plant species and genotypes concerning their ability to take up and accumulate TEs (Jolly et al. 2013; Gupta et al. 2019; Li et al. 2019). This ability depends in a first moment on the TEs bioavailability, and then, on the physiological mechanisms involved on TEs uptake and translocation (Antoniadis et al. 2017). In this sense, agricultural practices that influence TEs bioavailability (e.g., increase soil base saturation) often shape their accumulation in plants (Macedo et al. 2020). There was no effect of base saturation on pseudo-total $\mathrm{Ba}, \mathrm{Cd}, \mathrm{Cu}, \mathrm{Ni}$ and $\mathrm{Zn}$ concentrations in the contaminated Entisol, with few exceptions (Fig. 1). This result occurred because the effect of the higher $\mathrm{pH}$ and $\mathrm{CEC}$ resulting from the increasing base saturation often affects only the chemical distribution of the TEs into soluble, readily exchangeable, complexed with organic matter or hydrous oxides forms (Rieuwerts 2007). Therefore, normally there is no effect of $\mathrm{pH}$ and $\mathrm{CEC}$ on the pseudo-total TEs concentration. On the other hand, increasing base saturation decreased $\mathrm{Ba}, \mathrm{Cd}, \mathrm{Cu}, \mathrm{Ni}$ and $\mathrm{Zn}$ bioavailability in the Entisol (Pinto and Alleoni 2018), i.e., there was a reduction on TEs fractions that can be absorbed and involved in the plant cell metabolism. Similar results were pointed out in other studies, in which that $\mathrm{Ba}, \mathrm{Cd}, \mathrm{Cu}, \mathrm{Ni}$ and $\mathrm{Zn}$ bioavailability and toxicity on different plant species decreased after increasing base saturation by liming (Guo et al. 2013; Han et al. 2013; Myrvang et al. 2016a; Cioccio et al. 2017).

When present at high concentrations in plant tissues, $\mathrm{Ba}, \mathrm{Cd}, \mathrm{Cu}, \mathrm{Ni}$ and $\mathrm{Zn}$ inhibit plant growth and decrease photosynthetic activity (Moya et al. 1993; Gupta et al. 2019; Lavres et al. 2019). In our study, the biomass production of lettuce exposed to $\mathrm{Cu}$, Ni and $\mathrm{Zn}$ was strongly lower than the control (Figs. 2B-C), which also happened with the leaf $\mathrm{CO}_{2}$ assimilation and stomatal conductance of lettuce plants exposed to $\mathrm{Ni}$ and $\mathrm{Zn}$, especially at soil base saturation of $30 \%$ (Table 2). Possibly, the lower biomass observed in lettuce exposed to Ni and $\mathrm{Zn}$ is related to inhibitory effect of $\mathrm{Ni}$ and $\mathrm{Zn}$ in the activities of enzymes involved on photosynthetic carbon reduction cycle (Moya et al. 1993; Benzarti et al. 2008), and with changes on abscisic acid (ABA) synthesis that caused stomatal closure (Rucińska-Sobkowiak 2016). Rauser and Dumbroff (1981) reported that bean (Phaseolus vulgaris L.) exposed to $\mathrm{Ni}$ and $\mathrm{Zn}$ presented increased ABA concentrations that leaded to stomatal closure, lower transpiration, and water stress. On the other hand, the suppression Cu-induced on biomass of lettuce (Figs. 2B-C), as well as in rice (Figs. 2D-F), was not related to chlorophyll concentration and leaf $\mathrm{CO}_{2}$ assimilation (Table 2), suggesting that the toxicity $\mathrm{Cu}$-induced in these plants was not directly related to these photosynthetic processes. As a redox-active element, Cu can directly cause reactive oxygen species formation and induces lipid peroxidation of membranes and protein oxidation, leading to growth inhibition (Adrees et al. 2015), as reported for lettuce (Trujillo-Reyes et al. 2014) and rice (Da Costa et al. 2020).

Similarly to lettuce, sunflower was more susceptible to toxicity induced by Ni and Zn compared to the others TEs, especially when the plants were grown at soil base saturation of $30 \%$ (Figs. 2G-I). However, differently from lettuce, $\mathrm{Ni}$ and $\mathrm{Zn}$ did not induce great changes on photosynthetic parameters measured in sunflower (Table 2). Despite Ni and Zn can decrease photosynthetic activity of plants, these TEs also can induce other metabolic disorders that compromise the biomass production, such as oxidative stress (Akladious and Mohamed 2017; Shahbaz et al. 2018).

Oxidative stress has often been discussed as a primary effect of TEs exposure in plants (Clemens 2006). Shahbaz et al. (2018) assessed the toxicity Ni-induced in sunflower grown in a Ni-polluted soil $\left(77 \mathrm{mg} \mathrm{Ni} \mathrm{kg}^{-1}\right)$ and reported that the oxidative stress Ni-induced strongly decreased the plant biomass. Shahbaz et al. (2018) also described that the use of biochar was essential to decrease Ni bioavailability and increase the biomass production of sunflower. In our study, we observed that increasing soil base saturation was essential to decrease $\mathrm{Ni}$ bioavailability, allowing the survival of sunflower grown on Ni-polluted Entisol (Figs. 2G-I). Similar results were reported by Macedo et al. (2020) in an Alfisol. Sunflower grown on Zn-polluted soil also had higher biomass at base saturation of 70\% (Figs. 2G-I), probably due to a lower $\mathrm{Zn}$ concentration in its shoot and grains (Figs. 3Q-R). Excess Zn may inactivate enzymes that mitigate oxidative stress, such as superoxide dismutase (EC 1.15.1.1), catalase (EC 1.11.1.6) and ascorbate peroxidase (EC 1.11.1.11) (Akladious and Mohamed 2017).

It is probable that oxidative stress or water stress or both had been the main cause for the lower root biomass of tomato grown on $\mathrm{Cd}, \mathrm{Cu}, \mathrm{Ni}$ or Zn-polluted Entisol at base saturation of 30\% (Fig. 2L). Metals often decrease elongation of the primary roots, impair secondary growth, increase roots dieback or reduce root hair by inducing oxidative stress, which exert deleterious effects on root-absorbing area and water 
uptake (Rucińska-Sobkowiak 2016; Ahmad et al. 2018). Despite Cd, Cu, Ni and Zn had decreased root biomass of tomato, only Ni exposure decreased fruits production compared to control in tomato plants grown at base saturation of $30 \%$ (Fig. $2 \mathrm{~J}$ ). Probably, this result is related to the high Ni concentration observed in the tomato fruits compared to the other TEs concentrations (Figs. 3A, 3E, 3I, 3M and 3Q).

The interval between levels of sufficiency and toxicity of Ni for plants is very short since this TE is required in low concentrations (Macedo et al. 2016, 2020). High Ni concentrations in tomato fruits can be a problem not only for plants but also for the human health (Correia et al. 2018). Nickel concentration recorded in the edible parts of the crops grown in the Ni-polluted Entisol in our study were above of the maximum permitted level (EPA-IRIS 1987b), which means that the intake of these crops by humans could lead to health problems (Petrosino et al. 2018).

As occurred with $\mathrm{Ni}$, the concentrations of $\mathrm{Ba}$ and $\mathrm{Cd}$ in the edible parts of the crops assayed exceeded the maximum levels permitted by EPA-IRIS (1987a), and FAO and WHO (2011), respectively, when the plants were grown in the Entisol spiked with TEs concentrations corresponding to the prevention levels proposed by CETESB (2014). According to CETESB (2014), harmful changes to soil and groundwater quality can occur in soils presenting TEs concentrations corresponding to the prevention levels, but direct and indirect potential risks to the human health are expected only in soils presenting TEs concentrations equal or above the intervention levels for agricultural areas.

Therefore, the prevention levels established by CETESB (2014) for Ba, Cd and Ni possibly should be revised for soils presenting low OC and clay contents, and low CEC such as Entisol (Rieuwerts 2007), because Ba, Cd and Ni concentrations recorded in the edible parts of the crops assayed in our study (Figs. 3A-B, 3E-F and 3M-N) were potentially dangerous to human health (Tchounwou et al. 2012; Petrosino et al. 2018), regardless of soil base saturation.

Entisol presents lower capacity to control TEs bioavailability compared to clayey soils presenting highest OC content and CEC, which favor TEs accumulation (Melo et al. 2014). This fact is clear if we consider that we spiked the Entisol with TEs in the order $\mathrm{Ba}>\mathrm{Zn}>\mathrm{Cu}>\mathrm{Ni}>\mathrm{Cd}$ (considering their concentration), and the crops assayed accumulated TEs in the following order: lettuce, $\mathrm{Ba}=\mathrm{Zn}>\mathrm{Cu}=\mathrm{Ni}>\mathrm{Cd}$; rice, $\mathrm{Zn}>$ $\mathrm{Ba}>\mathrm{Ni}>\mathrm{Cu}>\mathrm{Cd}$; sunflower, $\mathrm{Ba}>\mathrm{Zn}>\mathrm{Cu}>\mathrm{Ni}>\mathrm{Cd}$; and tomato, $\mathrm{Ba}=\mathrm{Zn}>\mathrm{Ni}>\mathrm{Cu}>\mathrm{Cd}$ (Figs. 3D, 3H, 3L, 3P and 3T). Maybe for its characteristics, increasing base saturation in Entisol was not so effective to reduce $\mathrm{Ba}, \mathrm{Cd}, \mathrm{Cu}, \mathrm{Ni}$ and $\mathrm{Zn}$ accumulation in lettuce, rice, sunflower and tomato (Figs. 3 and 4) when compared to other soils (Han et al. 2013; Cioccio et al. 2017; Li et al. 2019; Macedo et al. 2020).

The effect of increasing base saturation on TEs accumulation varied depending on metals and plants (Figs. 3 and 4 ) because TEs accumulation in the edible parts of the crops do not depend only on their bioavailability, but also on mechanisms involved on TEs uptake and translocation of each plant species (Antoniadis et al. 2017). To exemplify, lettuce grown at base saturation of $30 \%$ exceeded the maximum levels for Cu and Zn proposed by FAO and WHO (2011) (Figs. 3J and 3R), differently from rice and tomato. Sunflower also exceeded the maximum level for Zn proposed by FAO and WHO (2011) (Fig. 3Q).

As reported in other studies (Singh et al. 2010; Pereira et al. 2011; Melo et al. 2014; Gupta et al. 2019), Ba, Cd, Cu, Ni and Zn tissues' concentrations and BCFs for lettuce, rice, sunflower and tomato tissues followed the order: roots > shoot > grains or fruits (Figs. 3 and 4 ). Roots are normally the first structure of the plant in contact with TEs, and they present mechanisms to avoid excessive metals translocation, with exception of hyperaccumulators (Antoniadis et al. 2017; Gupta et al. 2019). Meng et al. (2019) reported that Cd was more accumulated in the roots than shoot in leafy vegetables due to the higher synthesis of phytochelatins [PCs, $(\gamma-G l u-C y s)$-Gly, with $n=2-11)]$ in the roots. Phytochelatins act on $\mathrm{Cd}^{2+}$ chelation and its transport from the cytosol to the vacuole (Clemens 2006). Kendziorek et al. (2016) suggested us that $\mathrm{Cd}$ and $\mathrm{Zn}$ distribution among roots and shoot was related to expression of the gene HMA4 (involved on metals efflux) in tomato roots. TEs translocation from roots to shoot mainly depends on the rate of trapping in compartments of root cells, the mobility within the root symplast and across barriers such as endodermis, loading into the xylem, and upward mobility in the xylem (Clemens and Ma 2016). Therefore, physiological mechanisms control TEs translocation from roots to shoot, although there is still a great influence of highest TEs bioavailability on their shoot accumulation due to the higher TEs uptake in this scenario. To exemplify, Melo et al. (2014) mentioned that there was a positive correlation of $\mathrm{Ba}$ and $\mathrm{Cd}$ bioavailability with $\mathrm{Ba} \mathrm{BCF}_{\text {roots }}, \mathrm{Ba} \mathrm{BCF}_{\text {shoot }}, \mathrm{Cd} \mathrm{BCF}_{\text {roots }}$ and $\mathrm{Cd} \mathrm{BCF}_{\text {shoot }}$ in different crops, but there was no correlation of TEs bioavailability with Ba TF and Cd TF.

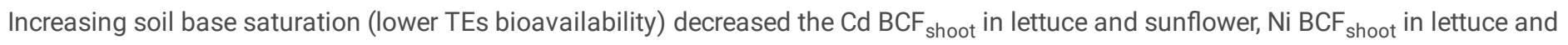
tomato, and $\mathrm{Zn} \mathrm{BCF}$ shoot in rice and sunflower grown in a polluted Entisol. Interestingly, there was no effect of soil base saturation on Ba and $\mathrm{Cu} \mathrm{BCF}$ shoot or $\mathrm{Ba}$ and $\mathrm{Cu} \mathrm{BCF}_{\text {grains or fruits }}$ in the crops assayed in our study (Figs. 4A-C, 4E-G, 4I-K, 4M-O and 4Q-S). Myrvang et al. (2016b) evaluated the effect of liming on Ba transfer from soil to shoot of different crops and observed that there was a great variation on $\mathrm{Ba} \mathrm{BCF}_{\text {shoot, }}$ regardless of Ba bioavailability, which was attributed to physiological differences between the plant species.

Trace elements accumulation in leaves (or shoot) depends on physiological factors such as TEs loading from xylem and the availability of metal-binding molecules (Clemens and Ma 2016), as observed in rice exposed to Cu (Ando et al. 2013). Furthermore, entering into the

Page $8 / 18$ 
shoots, some TEs such as Cu can be accumulated in the epidermis, which serves as an effective mechanism for their detoxification by decreasing metal influx into mesophyll (Seregin and Kozhevnikova 2020; van der Ent et al. 2020). These processes restrict TEs redistribution to grains and fruits (Seregin and Kozhevnikova 2020), and probably occurred in our study for Ba and Cu, because there was a strong restriction on $\mathrm{Ba}$ and $\mathrm{Cu}$ translocation from roots to edible parts of all crops compared to the other TEs (Fig. 4). Nevertheless, Hladun et al. (2015) stated that Cu presented high mobility inside radish (Raphanus sativus $\mathrm{L}$.). This finding reinforces that there is a great variation among plant species and genotypes concerning their ability to take up and accumulate TEs (Jolly et al. 2013; Gupta et al. 2019; Li et al. 2019).

Cadmium easily reached edible parts of the crops assayed compared to the other TEs, differently from the results observed for $\mathrm{Ba}$ and $\mathrm{Cu}$ (Figs. 4A-C, 4E-G, 4I-K, 4M-O and 4Q-S). Hladun et al. (2015) also mentioned that Cd presented high mobility inside radish. Meanwhile, Riesen and Feller (2005) described that $\mathrm{Ni}$ and $\mathrm{Zn}$ presented higher mobility inside wheat (Triticum aestivum L.) than Cd, and suggested that this result is associated with the plant capacity to transfer metals from xylem to phloem. However, this transfer process is unknown for the most TEs and crops, with exception for some TEs in rice (Clemens and Ma 2016; Seregin and Kozhevnikova 2020).

In our study, in general, lettuce, sunflower and tomato had lower capacity to restrict $\mathrm{Ba}, \mathrm{Cd}, \mathrm{Cu}, \mathrm{Ni}$ and $\mathrm{Zn}$ uptake and translocation than rice, even when rice grown in Entisol at a lower soil base saturation (50\% vs. 70\%) - Figs. 4A-C, 4E-G, 4I-K, 4M-O and 4Q-S. Probably this result is related to an efficient control of TEs distribution to shoot from the nodes of rice, which is a hub for metals distribution in graminaceous (Yamaji and Ma 2014). The distribution of TEs among leaves and grains in rice depends on phloem loading, the efficiency of xylem-tophloem transfer, the rates of various symplast-to-apoplast and apoplast-to-symplast transport processes, and the availability of storage sites (Clemens and Ma 2016). Several types of metal-binding compounds including nicotianamine and PCs were reported to be relevant for TEs transport in the phloem of crops destined to human feed (Gupta et al. 2019). These compounds can affect TEs translocation to grains or fruits since the roots, as observed in rice and tomato (Morishita et al. 1983). However, although there are studies evaluating TEs accumulation in plants, most processes involved on TEs translocation are still poorly known or unknown for the most plant species consumed by humans (Seregin and Kozhevnikova 2020).

\section{Conclusions}

In general, increasing soil base saturation did not attenuate photosynthetic changes induced by $\mathrm{Ba}, \mathrm{Cd}, \mathrm{Cu}, \mathrm{Ni}$ and $\mathrm{Zn}$ in the crops cultivated in the Entisol, since this agricultural practice was not so effective in reducing these TEs bioaccumulation.

The photosynthetic changes observed in the crops assayed varied depending on the metal and plant species. There was no a strong correlation between the photosynthetic parameters measured and biomass production, which suggest us that the suppression on biomass induced by $\mathrm{Ba}, \mathrm{Cd}, \mathrm{Cu}, \mathrm{Ni}$ or $\mathrm{Zn}$ is related to other metabolic disorders besides the impairment on $\mathrm{CO}_{2}$ assimilation or chlorophyll synthesis in the crops assayed, with exception of $\mathrm{Ni}$ and $\mathrm{Zn}$ in lettuce. Increasing soil base saturation was not consistent in decreasing $\mathrm{Ba}, \mathrm{Cd}, \mathrm{Cu}, \mathrm{Ni}$ and $\mathrm{Zn}$ accumulation in the edible parts of lettuce, rice, sunflower and tomato grown in the Entisol, which probably was related to the low capacity of this soil in control TEs bioavailability due to its low organic carbon and clay contents and low cation exchange capacity.

Barium, $\mathrm{Cd}, \mathrm{Cu}, \mathrm{Ni}$ and $\mathrm{Zn}$ bioaccumulation in the edible parts of the crops was affected by TEs bioavailability, which means that other agricultural practices maybe can be more efficient than increasing soil base saturation to avoid the bioaccumulation of TEs into edible parts of crops grown in Entisol. There was a great variation on $\mathrm{Ba}, \mathrm{Cd}, \mathrm{Cu}, \mathrm{Ni}$ and $\mathrm{Zn}$ translocation, which is associated to physiological mechanisms of each crop, but this process is still poorly known or unknown.

\section{Declarations}

\section{Author contributions}

FHSR wrote and revised the manuscript; JL performed the analysis; FAP performed the experiment and data collection; LRFA supervised the study and obtained financial support. All authors read and approved the final manuscript.

\section{Funding}

This research was supported by Coordination for the Improvement of Higher Education Personnel - CAPES (grant \#PROEX0061042), and by Scientific and Technological Brazilian Council - CNPq (grant \#307663/2014-0), Brazil.

\section{Compliance with ethical standards}

Conflict of interest The authors have no conflicts of interest to declare that are relevant to the content of this article. 
Availability of data and material Not applicable.

Code availability Not applicable.

Ethics approval Not applicable.

Consent to participate Not applicable.

Consent for publication Not applicable.

\section{References}

Adrees, M., Ali, S., Rizwan, M., Ibrahim, M., Abbas, F., Farid, M., Zia-ur-Rehman, M., Irshad, M.K., Bharwana, S.A., 2015. The effect of excess copper on growth and physiology of important food crops: a review. Environ. Sci. Pollut. Res. 22, 8148-8162.

Ahmad, P., Ahanger, M.A., Alyemeni, M.N., Wijaya, L., Alam, P., 2018. Exogenous application of nitric oxide modulates osmolyte metabolism, antioxidants, enzymes of ascorbate-glutathione cycle and promotes growth under cadmium stress in tomato. Protoplasma 255, 79-93.

Akladious, S.A., Mohamed, H.I., 2017. Physiological role of exogenous nitric oxide in improving performance, yield and some biochemical aspects of sunflower plant under zinc stress. Acta Biol. Hung. 68, 101-114.

Ando, Y., Nagata, S., Yanagisawa, S., Yoneyama, T., 2013. Copper in xylem and phloem saps from rice (Oryza sativa): the effect of moderate copper concentrations in the growth medium on the accumulation of five essential metals and a speciation analysis of copper-containing compounds. Funct. Plant Biol. 40, 89-100.

Antoniadis, V., Levizou, E., Shaheen, S.M., Ok, Y.S., Sebastian, A., Baum, C., Prasad, M.N.V., Wenzel, W.W., Rinklebe, J., 2017. Trace elements in the soil-plant interface: Phytoavailability, translocation, and phytoremediation - a review. Earth-Sci. Rev. 171, 621-645.

Benzarti, S., Mohri, S., Ono, Y., 2008. Plant Response to heavy metal toxicity: comparative study between the hyperaccumulator Thlaspi caerulescens (ecotype Ganges) and nonaccumulator plants: Lettuce, Radish, and Alfalfa. Environ. Toxicol. 23, 607-616.

Cardoso-Silva, S., Ferreira, P.A.L., Moschini-Carlos, V., Figueira, R.C.L., Pompêo, M., 2016. Temporal and spatial accumulation of heavy metals in the sediments at Paiva Castro Reservoir (São Paulo, Brazil). Environ. Earth Sci. 75, 9.

CETESB - The Environmental Company of São Paulo, 2014. Guiding Values for Soil and Groundwater in the State of São Paulo. São Paulo, Brazil. Available online: https://cetesb.sp.gov.br/solo/wp-content/uploads/sites/18/2014/12/valores-orientadores-nov-2014.pdf, Accessed date: 02 October 2020 (In Portuguese).

Cioccio, S., Gopalapillai, Y., Dan, T., Hale, B., 2017. Effect of liming on nickel bioavailability and toxicity to oat and soybean grown in field soils containing aged emissions from a nickel refinery. Environ. Toxicol. Chem. 36, 1110-1119.

Clemens, S., 2006. Toxic metal accumulation, responses to exposure and mechanisms of tolerance in plants. Biochimie 88, $1707-1719$.

Clemens, S., Ma, J.F., 2016. Toxic heavy metal and metalloid accumulation in crop plants and foods. Annu. Rev. Plant Biol. 67, 12.1-12.24.

Correia, L., Marrocos, P., Montalván Olivares, D.M., Velasco, F.G., Luzardo, F.H.M., Mota de Jesus, R., 2018. Bioaccumulation of nickel in tomato plants: risks to human health and agro-environmental impacts. Environ. Monit. Assess. 190, 317.

Da Costa, M.V.J., Kevat, N., Sharma, P.K., 2020. Copper oxide nanoparticle and copper (II) ion exposure in Oryza sativa reveals two different mechanisms of toxicity. Water Air Soil Pollut. 231, 258.

EMBRAPA - Brazilian Agricultural Research Corporation, 1997. Manual of Chemical Analysis of Soils, Plants and Fertilizers. Embrapa Comunicação para Transferência de Tecnologia, Brasília (In Portuguese).

EPA-IRIS - Environmental Protection Agency's Integrated Risk Information System, 1987a. Barium and Compounds; CASRN 7440-39-3. Integrated Risk Information System (IRIS) Chemical Assessment Summary, File First On-Line 01/31/1987. Available online: https://cfpub.epa.gov/ncea/iris/iris_documents/documents/subst/0010_summary.pdf, Accessed date: 02 November 2020.

EPA-IRIS - Environmental Protection Agency's Integrated Risk Information System, 1987b. Nickel, soluble salts; CASRN Various. Integrated Risk Information System (IRIS) Chemical Assessment Summary, File First On-Line 09/30/1987. Available online:

Page $10 / 18$ 
https://cfpub.epa.gov/ncea/iris/iris_d ocuments/documents/subst/0271_summary.pdf, Accessed date: 02 November 2020.

FAO and WHO - Food and Agriculture Organization of the United Nations for the World Health Organization, 2011. Joint FAO/WHO Food Standards Programme Codex Committee on Contaminants in Foods. Fifth Session, The Hague, The Netherlands. Available online: http://www.fao.org/tempref/codex/Meetings/CCCF/CCCF5/cf05_INF.pdf, Accessed date: 27 October 2020.

Gee, G.W., Bauder, J., 2002. Particle-size analysis. In: Dane, J.H., Toop, G.C. (Eds.), Methods of Soils Analysis. Part 4: Physical Methods. Soil Science Society of America, Madison, WI, pp. 255-293.

Guo, X., Wei, Z., Penn, C.J., Xu, T., Wu, Q., 2013. Effect of soil washing and liming on bioavailability of heavy metals in acid contaminated soil. Soil Sci. Soc. Am. J. 77, 432-441.

Gupta, N., Yadav, K.K., Kumar, V., Kumar, S., Chadd, R.P., Kumar, A., 2019. Trace elements in soil-vegetables interface: Translocation, bioaccumulation, toxicity and amelioration - A review. Sci. Total Environ. 651, 2927-2942.

Han, C., Wu, L., Tan, W., Luo, Y., 2013. Bioavailability and accumulation of cadmium and zinc by Sedum plumbizincicola after liming of an agricultural soil subjected to acid mine drainage. Commun. Soil Sci. Plant Anal. 44, 1097-1105.

Hänsch, R., Mendel, R.R., 2009. Physiological functions of mineral micronutrients (Cu, Zn, Mn, Fe, Ni, Mo, B, Cl). Curr. Opin. Plant Biol. 12, 259-266.

Hladun, K.R., Parker, D.R., Trumble, J.T., 2015. Cadmium, copper, and lead accumulation and bioconcentration in the vegetative and reproductive organs of Raphanus sativus: implications for plant performance and pollination. J. Chem. Ecol. 41, 386-395.

Jolly, Y.N., Islam, A., Akbar, S., 2013. Transfer of metals from soil to vegetables and possible health risk assessment. SpringerPlus 2, 385.

Kabata-Pendias, A., 2011. Trace Elements in Soils and Plants. fourth ed. CRC Press, Boca Raton.

Kendziorek, M., Klimecka, M., Barabasz, A., Borg, S., Rudzka, J., Szczęsny, P., Antosiewicz, D.M., 2016. Engineering high Zn in tomato shoots through expression of AtHMA4 involves tissue-specific modification of endogenous genes. BMC Genomics 17, 625.

Lavres Junior, J., Reis, A.R., Nogueira, T.A.R., Cabral, C.P., Malavolta, E., 2011. Phosphorus uptake by upland rice from superphosphate fertilizers produced with sulfuric acid treatments of Brazilian phosphate rocks. Commun. Soil Sci. Plant Anal. 42, 1390-1403.

Lavres, J., Rabêlo, F.H.S., Capaldi, F.R., Reis, A.R., Rossi, M.L., Franco, M.R., Azevedo, R.A., Abreu-Junior, C.H., Nogueira, N.L., 2019. Investigation into the relationship among $\mathrm{Cd}$ bioaccumulation, nutrient composition, ultrastructural changes and antioxidative metabolism in lettuce genotypes under Cd stress. Ecotox. Environ. Safe. 170, 578-589.

Li, K., Cao, C., Ma, Y., Su, D., Li, J., 2019. Identification of cadmium bioaccumulation in rice (Oryza sativa L.) by the soil-plant transfer model and species sensitivity distribution. Sci. Total Environ. 692, 1022-1028.

Long, S.P., Bernacchi, C.J., 2003. Gas exchange measurements, what can they tell us about the underlying limitations to photosynthesis? Procedures and sources of error. J. Exp. Bot. 4, 2393-2401.

Macedo, F.G., Bresolin, J.D., Santos, E.F., Furlan, F., Lopes da Silva, W.T., Polacco, J.C., Lavres, J., 2016. Nickel availability in soil as influenced by liming and its role in soybean nitrogen metabolism. Front. Plant Sci. 7, 1358.

Macedo, F.G., Santos, E.F., Lavres, J., 2020. Agricultural crop influences availability of nickel in the rhizosphere; a study on base cation saturations, Ni dosages and crop succession. Rhizosphere 13, 100182.

Melo, L.C.A., Silva, E.B., Alleoni, L.R.F., 2014. Transfer of cadmium and barium from soil to crops grown in tropical soils. R. Bras. Ci. Solo 38, 1939-1949.

Meng, Y., Zhang, L., Wang, L., Zhou, C., Shangguan, Y., Yang, Y., 2019. Antioxidative enzymes activity and thiol metabolism in three leafy vegetables under Cd stress. Ecotox. Environ. Safe. 173, 214-224.

Morishita, T., Yamaguchi, A., Ohta, Y., 1983. Sulphur accumulation by tomato and rice root in relation to transport of heavy metals. Soil Sci. Plant Nutr. 29, 219-225. 
Moya, J.L., Ros, R., Picazo, I., 1993. Influence of cadmium and nickel on growth, net photosynthesis and carbohydrate distribution in rice plants. Photosynth. Res. 36, 75-80.

Myrvang, M.B., Gjengedal, E., Heim, M., Krogstad, T., Almås, Å.R., 2016a. Geochemistry of barium in soils supplied with carbonatite rock powder and barium uptake to plants. Appl. Geochem. 75, 1-8.

Myrvang, M.B., Bleken, M.A., Krogstad, T., Heim, M., Gjengedal, E., 2016b. Can liming reduce barium uptake by agricultural plants grown on sandy soil? J. Plant Nutr. Soil Sci. 179, 557-565.

Nelson, D.W., Sommer, L.E., 1982. Total carbon, organic carbon, and organic matter. In: Page, A.L. (Ed). Methods of soil analysis. American Society of Agronomy, Madison, WI, pp. 539-579.

Nogueira, T.A.R., Abreu-Junior, C.H., Alleoni, L.R.F., He, Z., Soares, M.R., Vieira, C.S., Lessa, L.G.F., Capra, G.F., 2018. Background concentrations and quality reference values for some potentially toxic elements in soils of São Paulo State, Brazil. J. Environ. Manage. 221, 10-19.

Pereira, B.F.F., Rozane, D.E., Araújo, S.R., Barth, G., Queiroz, R.J.B., Nogueira, T.A.R., Moraes, M.F., Cabral, C.P., Boaretto, A.E., Malavolta, E., 2011. Cadmium availability and accumulation by lettuce and rice. R. Bras. Ci. Solo 35, 645-654.

Petrosino, V., Motta, G., Tenore, G., Coletta, M., Guariglia, A., Testa, D., 2018. The role of heavy metals and polychlorinated biphenyls (PCBs) in the oncogenesis of head and neck tumors and thyroid diseases: a pilot study. Biometals 31, 285-295.

Pinto, F.A., Alleoni, L.R.F., 2018. Extractors for barium, cadmium, copper, nickel, and zinc in tropical soils. Commun. Soil Sci. Plant Anal. 49, 2478-2495.

Piotto, F.A., Carvalho, M.E.A., Souza, L.A., Rabêlo, F.H.S., Franco, M.R., Batagin-Piotto, K.D., Azevedo, R.A., 2018. Estimating tomato tolerance to heavy metal toxicity: cadmium as study case. Environ. Sci. Pollut. Res. 25, 27535-27544.

Raij, B. van, Quaggio, J.A., Silva, N.M., 1986. Extraction of phosphorus, potassium, calcium and magnesium from soils by an ion-exchange resin procedure. Commun. Soil Sci. Plant Anal. 17, 547-566.

Raij, B. van, Cantarella, H., Quaggio, J.A., Furlani, A.M.C., 1996. Fertilization and liming recommendations for the State of São Paulo. $2^{\text {nd }}$ edition. Agronomic Institute of Campinas, Campinas (IAC Technical Bulletin, 100) (In Portuguese).

Raij, B. van, Andrade, J.C., Cantarella, H., Quaggio, J.A., 2001. Chemical Analysis to Evaluate Fertility of Tropical Soils. Agronomic Institute of Campinas, Campinas (In Portuguese).

Rauser, W.E., Dumbroff, E.B., 1981. Effects of excess cobalt, nickel and zinc on the water relations of Phaseolus vulgaris. Environ. Exp. Bot. $21,249-255$.

Riesen, O., Feller, U., 2005. Redistribution of nickel, cobalt, manganese, zinc, and cadmium via the phloem in young and maturing wheat. J. Plant Nutr. 28, 421-430.

Rieuwerts, J.S., 2007. The mobility and bioavailability of trace metals in tropical soils: a review. Chem. Spec. Bioavailab. $19,75-85$.

Rucińska-Sobkowiak, R., 2016. Water relations in plants subjected to heavy metal stresses. Acta Physiol. Plant. $38,257$.

SAS Institute, 2008. SAS User's Guide: Statistics. Version 9.2, Cary, NC, USA. Available online: http://support.sas.com/software/92/, Accessed date: 02 October 2020.

Seregin, I.V., Kozhevnikova, A.D., 2020. Low-molecular-weight ligands in plants: role in metal homeostasis and hyperaccumulation. Photosynth. Res. 10.1007/s11120-020-00768-1.

Shahbaz, A.K., Lewinska, K., Iqbal, J., Ali, Q., Mahmood-ur-Rahman, Iqbal, M., Abbas, F., Tauqeer, H.M., Ramzani, P.M.A., 2018. Improvement in productivity, nutritional quality, and antioxidative defense mechanisms of sunflower (Helianthus annuus L.) and maize (Zea mays L.) in nickel contaminated soil amended with different biochar and zeolite ratios. J. Environ. Manage. 218, $256-270$.

Singh, A., Sharma, R.K., Agrawal, M., Marshall, F.M., 2010. Risk assessment of heavy metal toxicity through contaminated vegetables from waste water irrigated area of Varanasi, India. Trop. Ecol. 51, 375-387.

Page 12/18 
Tchounwou, P.B., Yedjou, C.G., Patlolla, A.K., Sutton, D.J., 2012. Heavy metals toxicity and the environment. Mol. Clin. Environ. Toxicol. 101, 133-164.

Trujillo-Reyes, J., Majumdar, S., Botez, C.E., Peralta-Videa, J.R., Gardea-Torresdey, J.L., 2014. Exposure studies of core-shell $\mathrm{Fe} / \mathrm{Fe}_{3} \mathrm{O}_{4}$ and $\mathrm{Cu} / \mathrm{CuO}$ NPs to lettuce (Lactuca sativa) plants: Are they a potential physiological and nutritional hazard? J. Hazard. Mater. 267, 255-263.

USEPA - United States Environmental Protection Agency, 2007. Method 3051A - Microwave Assisted Acid Digestion of Sediments, Sludges, Soils, and Oils. United States Environmental Protection Agency, Washington, DC. Available online: https://www.epa.gov/sites/production/files/2015-12/documents/3051a.pdf, Accessed date: 10 November 2020.

van der Ent, A., Vinya, R., Erskine, P.D., Malaisse, F., Przybyłowicz, W.J., Barnabas, A.D., Harris, H.H., Mesjasz-Przybyłowicz, J., 2020. Elemental distribution and chemical speciation of copper and cobalt in three metallophytes from the copper-cobalt belt in Northern Zambia. Metallomics 10.1039/c9mt00263d.

Yamaji, N., Ma, J.F., 2014. The node, a hub for mineral nutrient distribution in graminaceous plants. Trends Plant Sci. 19, 556-563.

\section{Tables}

Table 1 Descriptive analysis of some chemical and physical properties of the Entisol used in this study

\begin{tabular}{|c|c|c|c|}
\hline $\mathrm{pH} 0.01 \mathrm{~mol} \mathrm{~L}^{-1} \mathrm{CaCl}_{2}$ & 4.2 & $\mathrm{Al}\left(\mathrm{mmol}_{\mathrm{C}} \mathrm{kg}^{-1}\right)$ & 5 \\
\hline & & $\mathrm{H}+\mathrm{Al}\left(\mathrm{mmol}_{\mathrm{c}} \mathrm{kg}^{-1}\right)$ & 21 \\
\hline \multirow[t]{2}{*}{$\mathrm{P}\left(\mathrm{mg} \mathrm{dm}^{-3}\right)$} & 6 & & \\
\hline & & $\mathrm{SB}\left(\mathrm{mmol}_{\mathrm{c}} \mathrm{kg}^{-1}\right)$ & 3.3 \\
\hline $\mathrm{K}\left(\mathrm{mmol}_{\mathrm{c}} \mathrm{kg}^{-1}\right)$ & 0.3 & $\mathrm{CEC}_{7.0}\left(\mathrm{mmol}_{\mathrm{C}} \mathrm{kg}^{-1}\right)$ & 24.3 \\
\hline $\mathrm{Ca}\left(\mathrm{mmol}_{\mathrm{C}} \mathrm{kg}^{-1}\right)$ & 2 & & \\
\hline \multirow[t]{2}{*}{$\mathrm{Mg}\left(\mathrm{mmol}_{\mathrm{c}} \mathrm{kg}^{-1}\right)$} & 1 & BS (\%) & 13 \\
\hline & & m (\%) & 60 \\
\hline $\mathrm{Ba}\left(\mathrm{mg} \mathrm{kg}^{-1}\right)$ & 3.6 & & \\
\hline $\mathrm{Cd}\left(\mathrm{mg} \mathrm{kg}^{-1}\right)$ & 0.8 & $\mathrm{OC}\left(\mathrm{g} \mathrm{kg}^{-1}\right)$ & 5 \\
\hline $\mathrm{Cu}\left(\mathrm{mg} \mathrm{kg}^{-1}\right)$ & 15.2 & Sand $\left(\mathrm{g} \mathrm{kg}^{-1}\right)$ & 906 \\
\hline $\mathrm{Ni}\left(\mathrm{mg} \mathrm{kg}^{-1}\right)$ & 2.2 & Silt $\left(\mathrm{g} \mathrm{kg}^{-1}\right)$ & 31 \\
\hline $\mathrm{Zn}\left(\mathrm{mg} \mathrm{kg}^{-1}\right)$ & 14.5 & Clay $\left(\mathrm{g} \mathrm{kg}^{-1}\right)$ & 63 \\
\hline
\end{tabular}

SB: sum of bases; $\mathrm{CEC}_{7.0}$ : Cation Exchange Capacity at pH 7.0; BS: Base saturation; m: saturation by aluminum; OC - Organic Carbon.

Table 2 Leaf area, chlorophyll concentration, leaf $\mathrm{CO}_{2}$ assimilation - $A$, stomatal conductance - $g_{S}$ intracellular $\mathrm{CO}_{2}$ concentration - $C_{i}$ and transpiration - $E$ of lettuce, rice, sunflower, and tomato grown in unpolluted (control treatment) or $\mathrm{Ba}, \mathrm{Cd}, \mathrm{Cu}, \mathrm{Ni}$ or $\mathrm{Zn}$-polluted Entisol under two base saturation (BS\%) 


\begin{tabular}{|c|c|c|c|c|c|c|c|c|c|c|c|c|}
\hline \multirow{2}{*}{$\begin{array}{l}\text { Parameters } \\
\text { Lettuce }\end{array}$} & \multicolumn{2}{|c|}{$\begin{array}{l}\text { Leaf area } \\
\left(\mathrm{cm}^{2} / p o t\right)\end{array}$} & \multicolumn{2}{|c|}{$\begin{array}{l}\text { Chlorophyll } \\
\text { (SPAD } \\
\text { units) }\end{array}$} & \multicolumn{2}{|c|}{$\begin{array}{l}A\left(\mu \mathrm{mol} \mathrm{CO} \mathrm{CO}_{2}\right. \\
\left.\mathrm{m}^{-2} \mathrm{~s}^{-1}\right)\end{array}$} & \multicolumn{2}{|c|}{$\begin{array}{l}g_{s}\left(\mathrm{~mol} \mathrm{H}_{2} \mathrm{O}\right. \\
\left.\mathrm{m}^{-2} \mathrm{~s}^{-1}\right)\end{array}$} & \multicolumn{2}{|c|}{$\begin{array}{l}C_{i}(\mu \mathrm{mol} \\
\left.\mathrm{CO}_{2} \mathrm{~mol}^{-1}\right)\end{array}$} & \multicolumn{2}{|c|}{$\begin{array}{l}E\left(\mathrm{mmol} \mathrm{m} \mathrm{m}^{-2} \mathrm{~s}^{-}\right. \\
\left.{ }^{1}\right)\end{array}$} \\
\hline & $30 \%$ & $70 \%$ & $30 \%$ & $70 \%$ & $30 \%$ & $70 \%$ & $30 \%$ & $70 \%$ & $30 \%$ & $70 \%$ & $30 \%$ & $70 \%$ \\
\hline Control & $\begin{array}{l}853 \\
\pm 60 \\
\mathrm{Aa}\end{array}$ & $\begin{array}{l}1032 \\
\pm \\
100 \\
\mathrm{Aa}\end{array}$ & $\begin{array}{l}14.9 \\
\pm \\
1.9 \\
\text { Aab }\end{array}$ & $\begin{array}{l}13.2 \\
\pm \\
1.1 \\
\text { Aab }\end{array}$ & $\begin{array}{l}14.26 \\
\pm \\
2.06 \\
\text { Aa }\end{array}$ & $\begin{array}{l}10.98 \\
\pm \\
0.22 \\
\text { Aab }\end{array}$ & $\begin{array}{l}0.91 \\
\pm \\
0.05 \\
\mathrm{Aa}\end{array}$ & $\begin{array}{l}0.33 \\
\pm \\
0.09 \\
\text { Bab }\end{array}$ & $\begin{array}{l}353 \\
\pm 5 \\
\text { Aa }\end{array}$ & $\begin{array}{l}307 \\
\pm \\
10 \\
\mathrm{Aa}\end{array}$ & $\begin{array}{l}11.27 \\
\pm \\
0.78 \\
\mathrm{Aa}\end{array}$ & $\begin{array}{l}6.06 \\
\pm \\
1.19 \\
\mathrm{Ba}\end{array}$ \\
\hline $\mathrm{Ba}$ & $\begin{array}{l}1032 \\
\pm 99 \\
\mathrm{Aa}\end{array}$ & $\begin{array}{l}1142 \\
\pm \\
233 \\
\mathrm{Aa}\end{array}$ & $\begin{array}{l}14.8 \\
\pm \\
0.7 \\
\text { Aab }\end{array}$ & $\begin{array}{l}13.3 \\
\pm \\
0.9 \\
\text { Aab }\end{array}$ & $\begin{array}{l}8.11 \\
\pm \\
0.50 \\
\text { Aab }\end{array}$ & $\begin{array}{l}9.26 \\
\pm \\
0.12 \\
\text { Aabc }\end{array}$ & $\begin{array}{l}0.30 \\
\pm \\
0.05 \\
\text { Abc }\end{array}$ & $\begin{array}{l}0.09 \\
\pm \\
0.02 \\
\mathrm{Bbc}\end{array}$ & $\begin{array}{l}337 \\
\pm \\
11 \\
\mathrm{Aa}\end{array}$ & $\begin{array}{l}261 \\
\pm \\
16 \\
\mathrm{Ba}\end{array}$ & $\begin{array}{l}5.15 \\
\pm \\
0.40 \\
A b\end{array}$ & $\begin{array}{l}2.23 \\
\pm \\
0.57 \\
\mathrm{Bb}\end{array}$ \\
\hline $\mathrm{Cd}$ & $\begin{array}{l}971 \\
\pm 91 \\
\mathrm{Aa}\end{array}$ & $\begin{array}{l}1106 \\
\pm \\
152 \\
\mathrm{Aa}\end{array}$ & $\begin{array}{l}12.4 \\
\pm \\
0.6 \\
\text { Abc }\end{array}$ & $\begin{array}{l}11.6 \\
\pm \\
0.6 \\
A b\end{array}$ & $\begin{array}{l}14.44 \\
\pm \\
3.94 \\
\mathrm{Aa}\end{array}$ & $\begin{array}{l}12.25 \\
\pm \\
2.25 \\
\mathrm{Aa}\end{array}$ & $\begin{array}{l}0.56 \\
\pm \\
0.14 \\
\mathrm{Ab}\end{array}$ & $\begin{array}{l}0.05 \\
\pm \\
0.00 \\
\mathrm{BC}\end{array}$ & $\begin{array}{l}335 \\
\pm 8 \\
\text { Aa }\end{array}$ & $\begin{array}{l}256 \\
\pm \\
52 \\
\mathrm{Ba}\end{array}$ & $\begin{array}{l}8.76 \\
\pm \\
1.22 \\
\mathrm{Aa}\end{array}$ & $\begin{array}{l}1.36 \\
\pm \\
0.19 \\
\mathrm{Bb}\end{array}$ \\
\hline $\mathrm{Cu}$ & $\begin{array}{l}300 \\
\pm 38 \\
\mathrm{Bb}\end{array}$ & $\begin{array}{l}1285 \\
\pm \\
147 \\
\mathrm{Aa}\end{array}$ & $\begin{array}{l}16.4 \\
\pm \\
1.5 \\
\mathrm{Aa}\end{array}$ & $\begin{array}{l}15.0 \\
\pm \\
1.1 \\
\mathrm{Aa}\end{array}$ & $\begin{array}{l}12.89 \\
\pm \\
2.96 \\
\mathrm{Aa}\end{array}$ & $\begin{array}{l}11.09 \\
\pm \\
3.54 \\
\text { Aa }\end{array}$ & $\begin{array}{l}0.22 \\
\pm \\
0.05 \\
\text { Acd }\end{array}$ & $\begin{array}{l}0.36 \\
\pm \\
0.04 \\
\mathrm{Aa}\end{array}$ & $\begin{array}{l}279 \\
\pm 2 \\
\text { Aa }\end{array}$ & $\begin{array}{l}282 \\
\pm \\
35 \\
\mathrm{Aa}\end{array}$ & $\begin{array}{l}1.46 \\
\pm \\
0.64 \\
\mathrm{BC}\end{array}$ & $\begin{array}{l}6.42 \\
\pm \\
0.58 \\
\mathrm{Aa}\end{array}$ \\
\hline $\mathrm{Ni}$ & $\begin{array}{l}188 \\
\pm 21 \\
\mathrm{Bb}\end{array}$ & $\begin{array}{l}500 \\
\pm 29 \\
\mathrm{Ab}\end{array}$ & $\begin{array}{l}11.7 \\
\pm \\
1.9 \\
\text { AC }\end{array}$ & $\begin{array}{l}12.0 \\
\pm \\
0.0 \\
A b\end{array}$ & $\begin{array}{l}0.52 \\
\pm \\
0.11 \\
\mathrm{Ab}\end{array}$ & $\begin{array}{l}2.23 \\
\pm \\
0.35 \\
\text { Ac }\end{array}$ & $\begin{array}{l}0.03 \\
\pm \\
0.00 \\
\mathrm{Ad}\end{array}$ & $\begin{array}{l}0.03 \\
\pm \\
0.00 \\
\text { Ac }\end{array}$ & $\begin{array}{l}355 \\
\pm 6 \\
\text { Aa }\end{array}$ & $\begin{array}{l}288 \\
\pm \\
33 \\
\mathrm{Aa}\end{array}$ & $\begin{array}{l}0.81 \\
\pm \\
0.10 \\
\text { Ac }\end{array}$ & $\begin{array}{l}0.77 \\
\pm \\
0.17 \\
A b\end{array}$ \\
\hline Zn & $\begin{array}{l}196 \\
\pm 29 \\
\mathrm{Ab}\end{array}$ & $\begin{array}{l}206 \\
\pm 39 \\
\mathrm{Ab}\end{array}$ & $\begin{array}{l}12.4 \\
\pm \\
0.7 \\
\text { Abc }\end{array}$ & $\begin{array}{l}11.0 \\
\pm \\
1.2 \\
A b\end{array}$ & $\begin{array}{l}1.34 \\
\pm \\
0.39 \\
\mathrm{Ab}\end{array}$ & $\begin{array}{l}2.47 \\
\pm \\
0.50 \\
\text { Abc }\end{array}$ & $\begin{array}{l}0.03 \\
\pm \\
0.00 \\
\text { Acd }\end{array}$ & $\begin{array}{l}0.02 \\
\pm \\
0.00 \\
\text { Ac }\end{array}$ & $\begin{array}{l}289 \\
\pm \\
36 \\
\mathrm{Aa}\end{array}$ & $\begin{array}{l}234 \\
\pm \\
26 \\
\mathrm{Aa}\end{array}$ & $\begin{array}{l}1.69 \\
\pm \\
0.86 \\
\text { Ac }\end{array}$ & $\begin{array}{l}0.64 \\
\pm \\
0.03 \\
A b\end{array}$ \\
\hline Rice & $30 \%$ & $50 \%$ & $30 \%$ & $50 \%$ & $30 \%$ & $50 \%$ & $30 \%$ & $50 \%$ & $30 \%$ & $50 \%$ & $30 \%$ & $50 \%$ \\
\hline Control & $\begin{array}{l}2861 \\
\pm \\
142 \\
\text { Aab }\end{array}$ & $\begin{array}{l}3134 \\
\pm 58 \\
\mathrm{Aa}\end{array}$ & $\begin{array}{l}36.7 \\
\pm \\
0.3 \\
\text { Aa }\end{array}$ & $\begin{array}{l}34.7 \\
\pm \\
1.3 \\
\mathrm{Aa}\end{array}$ & $\begin{array}{l}11.88 \\
\pm \\
1.85 \\
\mathrm{Aa}\end{array}$ & $\begin{array}{l}12.22 \\
\pm \\
2.59 \\
\text { Aab }\end{array}$ & $\begin{array}{l}0.06 \\
\pm \\
0.00 \\
\text { Ad }\end{array}$ & $\begin{array}{l}0.11 \\
\pm \\
0.02 \\
\mathrm{Aa}\end{array}$ & $\begin{array}{l}158 \\
\pm \\
73 \\
A b\end{array}$ & $\begin{array}{l}188 \\
\pm 6 \\
\text { Aa }\end{array}$ & $\begin{array}{l}1.40 \\
\pm \\
0.02 \\
\text { Ac }\end{array}$ & $\begin{array}{l}2.42 \\
\pm \\
0.46 \\
A b\end{array}$ \\
\hline $\mathrm{Ba}$ & $\begin{array}{l}3328 \\
\pm \\
136 \\
\mathrm{Aa}\end{array}$ & $\begin{array}{l}3114 \\
\pm 63 \\
\mathrm{Aa}\end{array}$ & $\begin{array}{l}36.5 \\
\pm \\
0.6 \\
\text { Aa }\end{array}$ & $\begin{array}{l}36.0 \\
\pm \\
0.7 \\
\mathrm{Aa}\end{array}$ & $\begin{array}{l}14.21 \\
\pm \\
1.12 \\
\mathrm{Aa}\end{array}$ & $\begin{array}{l}16.18 \\
\pm \\
0.86 \\
\mathrm{Aa}\end{array}$ & $\begin{array}{l}0.27 \\
\pm \\
0.01 \\
\mathrm{Aa}\end{array}$ & $\begin{array}{l}0.20 \\
\pm \\
0.05 \\
\mathrm{Aa}\end{array}$ & $\begin{array}{l}277 \\
\pm 6 \\
\text { Aa }\end{array}$ & $\begin{array}{l}253 \\
\pm \\
26 \\
\mathrm{Aa}\end{array}$ & $\begin{array}{l}4.92 \\
\pm \\
0.36 \\
\mathrm{Aa}\end{array}$ & $\begin{array}{l}3.89 \\
\pm \\
0.89 \\
\text { Aab }\end{array}$ \\
\hline $\mathrm{Cd}$ & $\begin{array}{l}2994 \\
\pm 73 \\
\mathrm{Aa}\end{array}$ & $\begin{array}{l}3479 \\
\pm 25 \\
\mathrm{Aa}\end{array}$ & $\begin{array}{l}36.5 \\
\pm \\
0.2 \\
\mathrm{Aa}\end{array}$ & $\begin{array}{l}35.5 \\
\pm \\
0.6 \\
\mathrm{Aa}\end{array}$ & $\begin{array}{l}12.51 \\
\pm \\
1.05 \\
\mathrm{Ba}\end{array}$ & $\begin{array}{l}15.69 \\
\pm \\
0.34 \\
\mathrm{Aa}\end{array}$ & $\begin{array}{l}0.15 \\
\pm \\
0.01 \\
\text { Abcd }\end{array}$ & $\begin{array}{l}0.17 \\
\pm \\
0.00 \\
\mathrm{Aa}\end{array}$ & $\begin{array}{l}234 \\
\pm \\
23 \\
\text { Aab }\end{array}$ & $\begin{array}{l}259 \\
\pm \\
25 \\
\mathrm{Aa}\end{array}$ & $\begin{array}{l}3.22 \\
\pm \\
0.24 \\
\text { Aabc }\end{array}$ & $\begin{array}{l}4.42 \\
\pm \\
1.01 \\
\mathrm{Aa}\end{array}$ \\
\hline $\mathrm{Cu}$ & $\begin{array}{l}2159 \\
\pm \\
449 \\
b\end{array}$ & * & $\begin{array}{l}31.7 \\
\pm \\
2.8 \\
a\end{array}$ & * & $\begin{array}{l}15.44 \\
\pm \\
1.57 \\
a\end{array}$ & * & $\begin{array}{l}0.21 \\
\pm \\
0.03 \\
a b c\end{array}$ & * & $\begin{array}{l}233 \\
\pm \\
28 \\
a b\end{array}$ & * & $\begin{array}{l}4.09 \\
\pm \\
0.61 \\
a b\end{array}$ & * \\
\hline $\mathrm{Ni}$ & $\begin{array}{l}2704 \\
\pm \\
119 \\
\text { Aab }\end{array}$ & $\begin{array}{l}3061 \\
\pm 33 \\
\mathrm{Aa}\end{array}$ & $\begin{array}{l}32.9 \\
\pm \\
1.3 \\
\mathrm{Aa}\end{array}$ & $\begin{array}{l}30.6 \\
\pm \\
2.3 \\
\mathrm{Aa}\end{array}$ & $\begin{array}{l}11.05 \\
\pm .9 \\
0.94 \\
\text { Аa }\end{array}$ & $\begin{array}{l}8.56 \\
\pm \\
0.42 \\
A b\end{array}$ & $\begin{array}{l}0.11 \\
\pm \\
0.01 \\
\text { Acd }\end{array}$ & $\begin{array}{l}0.18 \\
\pm \\
0.03 \\
\mathrm{Aa}\end{array}$ & $\begin{array}{l}211 \\
\pm \\
22 \\
\text { Aab }\end{array}$ & $\begin{array}{l}264 \\
\pm \\
27 \\
\mathrm{Aa}\end{array}$ & $\begin{array}{l}2.56 \\
\pm \\
0.20 \\
\text { Abc }\end{array}$ & $\begin{array}{l}3.49 \\
\pm \\
0.42 \\
\text { Aab }\end{array}$ \\
\hline Zn & $\begin{array}{l}3359 \\
\pm \\
255 \\
\mathrm{Aa}\end{array}$ & $\begin{array}{l}3173 \\
\pm \\
238 \\
\mathrm{Aa}\end{array}$ & $\begin{array}{l}35.2 \\
\pm \\
0.6 \\
\mathrm{Aa}\end{array}$ & $\begin{array}{l}34.0 \\
\pm \\
0.9 \\
\mathrm{Aa}\end{array}$ & $\begin{array}{l}13.82 \\
\pm \\
0.65 \\
\text { Aa }\end{array}$ & $\begin{array}{l}12.36 \\
\pm \\
0.66 \\
\text { Aab }\end{array}$ & $\begin{array}{l}0.22 \\
\pm \\
0.03 \\
\text { Aab }\end{array}$ & $\begin{array}{l}0.18 \\
\pm \\
0.03 \\
\mathrm{Aa}\end{array}$ & $\begin{array}{l}252 \\
\pm \\
27 \\
\text { Aab }\end{array}$ & $\begin{array}{l}249 \\
\pm \\
33 \\
\mathrm{Aa}\end{array}$ & $\begin{array}{l}4.29 \\
\pm \\
0.47 \\
\text { Aab }\end{array}$ & $\begin{array}{l}3.57 \\
\pm \\
0.47 \\
\text { Aab }\end{array}$ \\
\hline Sunflower & $30 \%$ & $70 \%$ & $30 \%$ & $70 \%$ & $30 \%$ & $70 \%$ & $30 \%$ & $70 \%$ & $30 \%$ & $70 \%$ & $30 \%$ & $70 \%$ \\
\hline Control & $\begin{array}{l}3213 \\
\pm \\
459 \\
\mathrm{Aa}\end{array}$ & $\begin{array}{l}3816 \\
\pm \\
405 \\
\text { Aab }\end{array}$ & $\begin{array}{l}31.2 \\
\pm \\
0.5 \\
\mathrm{Aa}\end{array}$ & $\begin{array}{l}31.5 \\
\pm \\
0.4 \\
\mathrm{Aa}\end{array}$ & $\begin{array}{l}17.89 \\
\pm \\
1.19 \\
\text { Aab }\end{array}$ & $\begin{array}{l}23.17 \\
\pm \\
2.18 \\
\mathrm{Aa}\end{array}$ & $\begin{array}{l}0.15 \\
\pm \\
0.00 \\
\mathrm{Bb}\end{array}$ & $\begin{array}{l}1.13 \\
\pm \\
0.13 \\
\mathrm{Aa}\end{array}$ & $\begin{array}{l}170 \\
\pm \\
10 \\
\mathrm{Ba}\end{array}$ & $\begin{array}{l}322 \\
\pm \\
20 \\
\mathrm{Aa}\end{array}$ & $\begin{array}{l}3.94 \\
\pm \\
0.00 \\
\text { Bbc }\end{array}$ & $\begin{array}{l}10.39 \\
\pm \\
0.01 \\
\mathrm{Aa}\end{array}$ \\
\hline $\mathrm{Ba}$ & $\begin{array}{l}2948 \\
\pm\end{array}$ & $\begin{array}{l}3990 \\
\pm\end{array}$ & $\begin{array}{l}34.0 \\
\pm\end{array}$ & $\begin{array}{l}31.5 \\
\pm\end{array}$ & $\begin{array}{l}11.58 \\
\pm\end{array}$ & $\begin{array}{l}25.20 \\
\pm\end{array}$ & $\begin{array}{l}0.13 \\
\pm\end{array}$ & $\begin{array}{l}0.94 \\
\pm\end{array}$ & $\begin{array}{l}213 \\
\pm\end{array}$ & $\begin{array}{l}295 \\
\pm\end{array}$ & $\begin{array}{l}3.00 \\
\pm\end{array}$ & $\begin{array}{l}10.27 \\
\pm\end{array}$ \\
\hline
\end{tabular}




\begin{tabular}{|c|c|c|c|c|c|c|c|c|c|c|c|c|}
\hline & $\begin{array}{l}515 \\
\mathrm{Aa}\end{array}$ & $\begin{array}{l}284 \\
\mathrm{Aa}\end{array}$ & $\begin{array}{l}0.1 \\
\mathrm{Aa}\end{array}$ & $\begin{array}{l}0.7 \\
\mathrm{Aa}\end{array}$ & $\begin{array}{l}0.77 \\
\mathrm{Bb}\end{array}$ & $\begin{array}{l}3.44 \\
\mathrm{Aa}\end{array}$ & $\begin{array}{l}0.06 \\
\mathrm{Bb}\end{array}$ & $\begin{array}{l}0.06 \\
\mathrm{Aa}\end{array}$ & $\begin{array}{l}43 \\
\mathrm{Ba}\end{array}$ & $\begin{array}{l}15 \\
\text { Aab }\end{array}$ & $\begin{array}{l}1.15 \\
\text { Bc }\end{array}$ & $\begin{array}{l}0.21 \\
\mathrm{Aa}\end{array}$ \\
\hline $\mathrm{Cd}$ & $\begin{array}{l}2096 \\
\pm \\
573 \\
\mathrm{Bab}\end{array}$ & $\begin{array}{l}4188 \\
\pm \\
366 \\
\mathrm{Aa}\end{array}$ & $\begin{array}{l}30.3 \\
\pm \\
1.8 \\
\text { Aab }\end{array}$ & $\begin{array}{l}30.5 \\
\pm \\
1.0 \\
\mathrm{Aa}\end{array}$ & $\begin{array}{l}20.39 \\
\pm \\
4.86 \\
\text { Aab }\end{array}$ & $\begin{array}{l}21.94 \\
\pm \\
3.95 \\
\mathrm{Aa}\end{array}$ & $\begin{array}{l}0.35 \\
\pm \\
0.20 \\
\text { Aab }\end{array}$ & $\begin{array}{l}0.70 \\
\pm \\
0.18 \\
\text { Aab }\end{array}$ & $\begin{array}{l}208 \\
\pm \\
44 \\
\mathrm{Aa}\end{array}$ & $\begin{array}{l}285 \\
\pm \\
24 \\
\text { Aab }\end{array}$ & $\begin{array}{l}5.52 \\
\pm \\
1.95 \\
\text { Aab }\end{array}$ & $\begin{array}{l}8.82 \\
\pm \\
1.12 \\
\mathrm{Aa}\end{array}$ \\
\hline $\mathrm{Cu}$ & $\begin{array}{l}2345 \\
\pm 7 \\
\text { Aa }\end{array}$ & $\begin{array}{l}2085 \\
\pm \\
337 \\
\text { Aab }\end{array}$ & $\begin{array}{l}31.7 \\
\pm \\
6.5 \\
\mathrm{Aa}\end{array}$ & $\begin{array}{l}35.4 \\
\pm \\
0.5 \\
\mathrm{Aa}\end{array}$ & $\begin{array}{l}28.68 \\
\pm \\
2.51 \\
\mathrm{Aa}\end{array}$ & $\begin{array}{l}23.22 \\
\pm \\
6.02 \\
\mathrm{Aa}\end{array}$ & $\begin{array}{l}0.83 \\
\pm \\
0.08 \\
\mathrm{Aa}\end{array}$ & $\begin{array}{l}0.11 \\
\pm \\
0.00 \\
\mathrm{Bb}\end{array}$ & $\begin{array}{l}279 \\
\pm \\
12 \\
\mathrm{Aa}\end{array}$ & $\begin{array}{l}214 \\
\pm \\
28 \\
\text { Aab }\end{array}$ & $\begin{array}{l}9.86 \\
\pm \\
0.37 \\
\mathrm{Aa}\end{array}$ & $\begin{array}{l}3.00 \\
\pm \\
0.00 \\
\mathrm{Bb}\end{array}$ \\
\hline $\mathrm{Ni}$ & * & $\begin{array}{l}1757 \\
\pm \\
335 \\
b\end{array}$ & * & $\begin{array}{l}33.9 \\
\pm \\
0.9 \\
a\end{array}$ & * & $\begin{array}{l}27.10 \\
\pm \\
5.53 \\
a\end{array}$ & * & $\begin{array}{l}0.54 \\
\pm \\
0.23 \\
a b\end{array}$ & * & $\begin{array}{l}202 \\
\pm \\
26 \\
b\end{array}$ & * & $\begin{array}{l}6.93 \\
\pm \\
1.94 \\
a b\end{array}$ \\
\hline $\mathrm{Zn}$ & $\begin{array}{l}1879 \\
\pm \\
197 \\
\mathrm{Ab}\end{array}$ & $\begin{array}{l}3314 \\
\pm \\
120 \\
\text { Aab }\end{array}$ & $\begin{array}{l}21.2 \\
\pm \\
1.2 \\
\mathrm{Bb}\end{array}$ & $\begin{array}{l}28.0 \\
\pm \\
0.5 \\
\mathrm{Aa}\end{array}$ & $\begin{array}{l}27.15 \\
\pm \\
0.01 \\
\text { Aab }\end{array}$ & $\begin{array}{l}25.89 \\
\pm \\
2.93 \\
\mathrm{Aa}\end{array}$ & $\begin{array}{l}0.38 \\
\pm \\
0.04 \\
\text { Aab }\end{array}$ & $\begin{array}{l}0.62 \\
\pm \\
0.21 \\
\text { Aab }\end{array}$ & $\begin{array}{l}196 \\
\pm \\
14 \\
\text { Aa }\end{array}$ & $\begin{array}{l}238 \\
\pm \\
56 \\
\text { Aab }\end{array}$ & $\begin{array}{l}4.23 \\
\pm \\
1.11 \\
\mathrm{Bbc}\end{array}$ & $\begin{array}{l}8.25 \\
\pm \\
1.96 \\
\mathrm{Aa}\end{array}$ \\
\hline Tomato & $30 \%$ & $70 \%$ & $30 \%$ & $70 \%$ & $30 \%$ & $70 \%$ & $30 \%$ & $70 \%$ & $30 \%$ & $70 \%$ & $30 \%$ & $70 \%$ \\
\hline Control & - & - & $\begin{array}{l}39.8 \\
\pm \\
2.9 \\
\mathrm{Aa}\end{array}$ & $\begin{array}{l}42.5 \\
\pm \\
0.7 \\
\mathrm{Aa}\end{array}$ & - & - & - & - & - & - & - & - \\
\hline $\mathrm{Ba}$ & - & - & $\begin{array}{l}39.7 \\
\pm \\
1.7 \\
\mathrm{Aa}\end{array}$ & $\begin{array}{l}40.9 \\
\pm \\
1.6 \\
\mathrm{Aa}\end{array}$ & - & - & - & - & - & - & - & - \\
\hline $\mathrm{Cd}$ & - & - & $\begin{array}{l}38.4 \\
\pm \\
4.0 \\
\mathrm{Aa}\end{array}$ & $\begin{array}{l}36.5 \\
\pm \\
1.5 \\
\mathrm{Aa}\end{array}$ & - & - & - & - & - & - & - & - \\
\hline $\mathrm{Cu}$ & - & - & $\begin{array}{l}45.5 \\
\pm \\
4.2 \\
\mathrm{Aa}\end{array}$ & $\begin{array}{l}43.4 \\
\pm \\
3.6 \\
\mathrm{Aa}\end{array}$ & - & - & - & - & - & - & - & - \\
\hline $\mathrm{Ni}$ & - & - & $\begin{array}{l}49.3 \\
\pm \\
2.2 \\
\mathrm{Aa}\end{array}$ & $\begin{array}{l}45.8 \\
\pm \\
1.2 \\
\mathrm{Aa}\end{array}$ & - & - & - & - & - & - & - & - \\
\hline $\mathrm{Zn}$ & - & - & $\begin{array}{l}37.3 \\
\pm \\
6.0 \\
\mathrm{Aa}\end{array}$ & $\begin{array}{l}42.8 \\
\pm \\
0.6 \\
\text { Аa }\end{array}$ & - & - & - & - & - & - & - & - \\
\hline
\end{tabular}

Means followed by distinct upper case letters indicate difference between base saturation within each condition (Control = unpolluted, or Ba, $\mathrm{Cd}, \mathrm{Cu}, \mathrm{Ni}$ or $\mathrm{Zn}$-polluted Entisol) for each crop, and distinct lower case letters indicate difference between each condition (Control = unpolluted, or $\mathrm{Ba}, \mathrm{Cd}, \mathrm{Cu}, \mathrm{Ni}$ or $\mathrm{Zn}$-polluted Entisol) within each base saturation for each crop (Tukey test, $\mathrm{P} \leq 0.05)$. Asterisks $\left({ }^{*}\right)$ indicate treatment lost due to plant death

\section{Figures}





Figure 1

Pseudo-total concentrations of $\mathrm{Ba}(\mathrm{A}), \mathrm{Cd}(\mathrm{B}), \mathrm{Cu}(\mathrm{C}), \mathrm{Ni}(\mathrm{D})$ and $\mathrm{Zn}$ in unpolluted (control treatment) or $\mathrm{Ba}, \mathrm{Cd}, \mathrm{Cu}, \mathrm{Ni}$ or Zn-polluted Entisol cultivated with lettuce, rice, sunflower or tomato under two soil base saturation (BS\%). Distinct upper case letters indicate difference between base saturation within each crop for each condition (unpolluted or polluted Entisol) and distinct lower case letters indicate difference between unpolluted or polluted Entisol within each base saturation for each crop (Tukey test, $P \leq 0.05$ ). The dash line (in red) indicates the trace elements concentrations corresponding to the prevention levels established by The São Paulo State Environmental Agency - CETESB, in Brazil (CETESB 2014) 

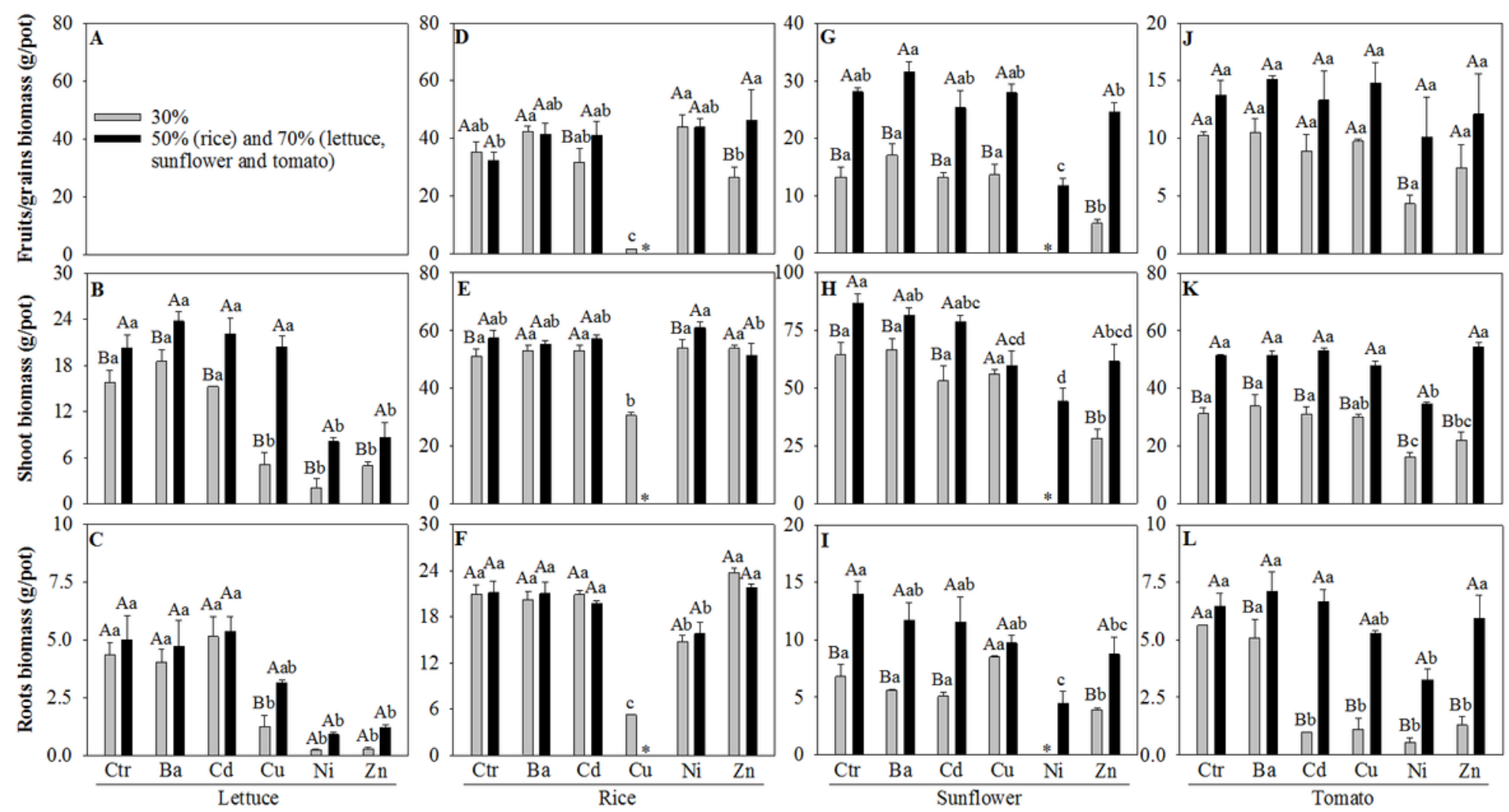

\section{Figure 2}

Fruits or grains biomass (A, D, G and J), shoot biomass (B, E, H and K) and root biomass (C, F, I and L) of lettuce (A-C), rice (D-F), sunflower (G-I), and tomato (J-L) grown in unpolluted (control treatment) or $\mathrm{Ba}, \mathrm{Cd}, \mathrm{Cu}, \mathrm{Ni}$ or Zn-polluted Entisol under two soil base saturation (BS\%). Distinct upper case letters indicate difference between base saturation within each condition (Ctr. - unpolluted or $\mathrm{Ba}, \mathrm{Cd}, \mathrm{Cu}, \mathrm{Ni}$ or $\mathrm{Zn}$ polluted Entisol) for each crop and distinct lower case letters indicate difference between each condition (Ctr. - unpolluted or $\mathrm{Ba}, \mathrm{Cd}, \mathrm{Cu}, \mathrm{Ni}$ or Zn-polluted Entisol) within each base saturation for each crop (Tukey test, $\mathrm{P} \leq 0.05$ ). Asterisks ${ }^{*}$ ) indicate treatment lost due to plant death
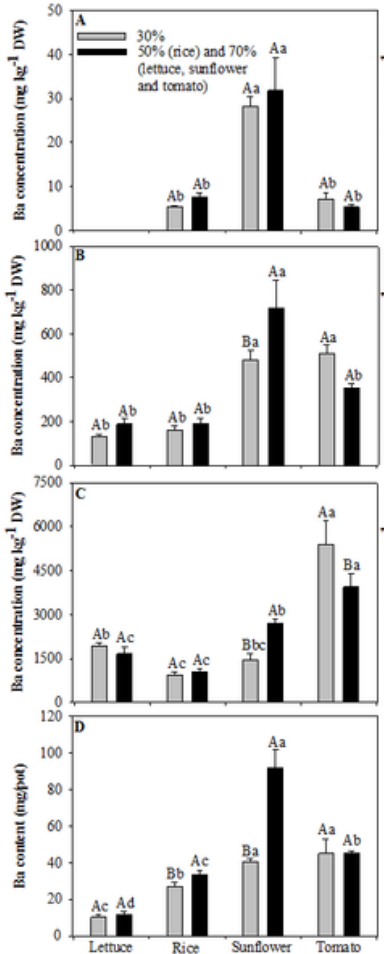
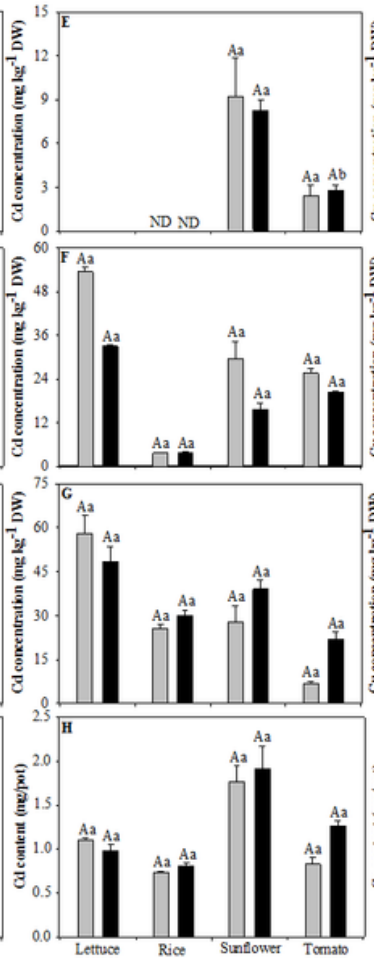
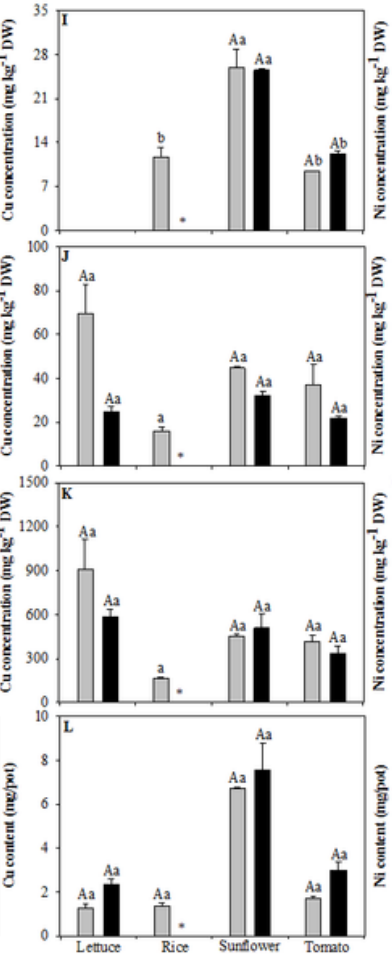
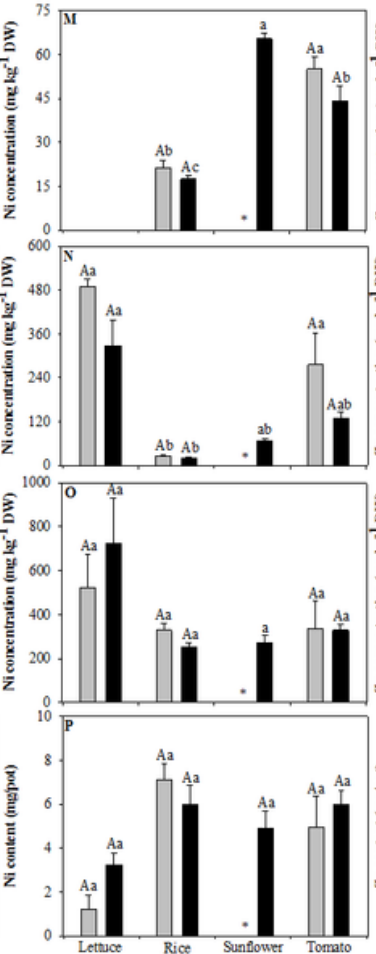

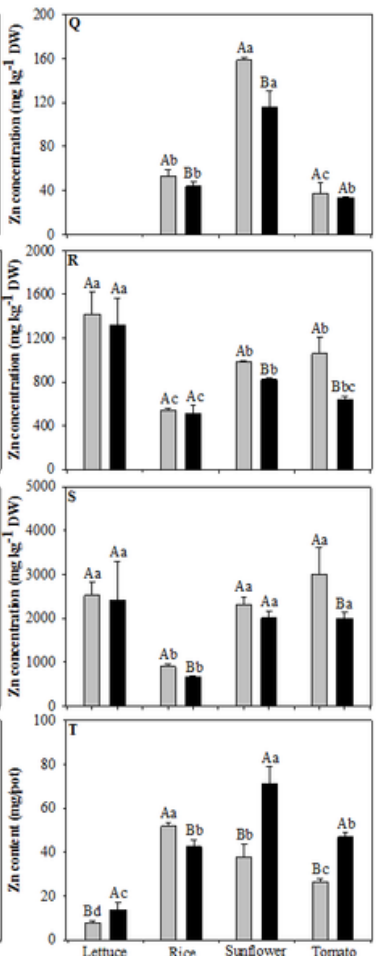


Figure 3

Concentrations of $\mathrm{Ba}(\mathrm{A}-\mathrm{C}), \mathrm{Cd}(\mathrm{E}-\mathrm{G}), \mathrm{Cu}(\mathrm{I}-\mathrm{K}), \mathrm{Ni}(\mathrm{M}-\mathrm{O})$ and $\mathrm{Zn}(\mathrm{Q}-\mathrm{S})$ in fruits or grains (A, E, I, M and Q), shoot (B, F, J, N and R) and roots (C, $\mathrm{G}, \mathrm{K}, \mathrm{O}$ and $\mathrm{S}$ ) and total content of $\mathrm{Ba}(\mathrm{D}), \mathrm{Cd}(\mathrm{H}), \mathrm{Cu}(\mathrm{L}), \mathrm{Ni}(\mathrm{P})$ and $\mathrm{Zn}(\mathrm{T})$ in lettuce, rice, sunflower and tomato grown on $\mathrm{Ba}, \mathrm{Cd}, \mathrm{Cu}, \mathrm{Ni}$ or Zn-polluted Entisol under two soil base saturation (BS\%). Distinct upper case letters indicate difference between base saturation within each crop for each trace element and distinct lower case letters indicate difference between each trace element within each base saturation for each crop (Tukey test, $\mathrm{P} \leq 0.05$ ). Asterisks $(*)$ indicate treatment lost due to plant death. $\mathrm{ND}=$ non-detected
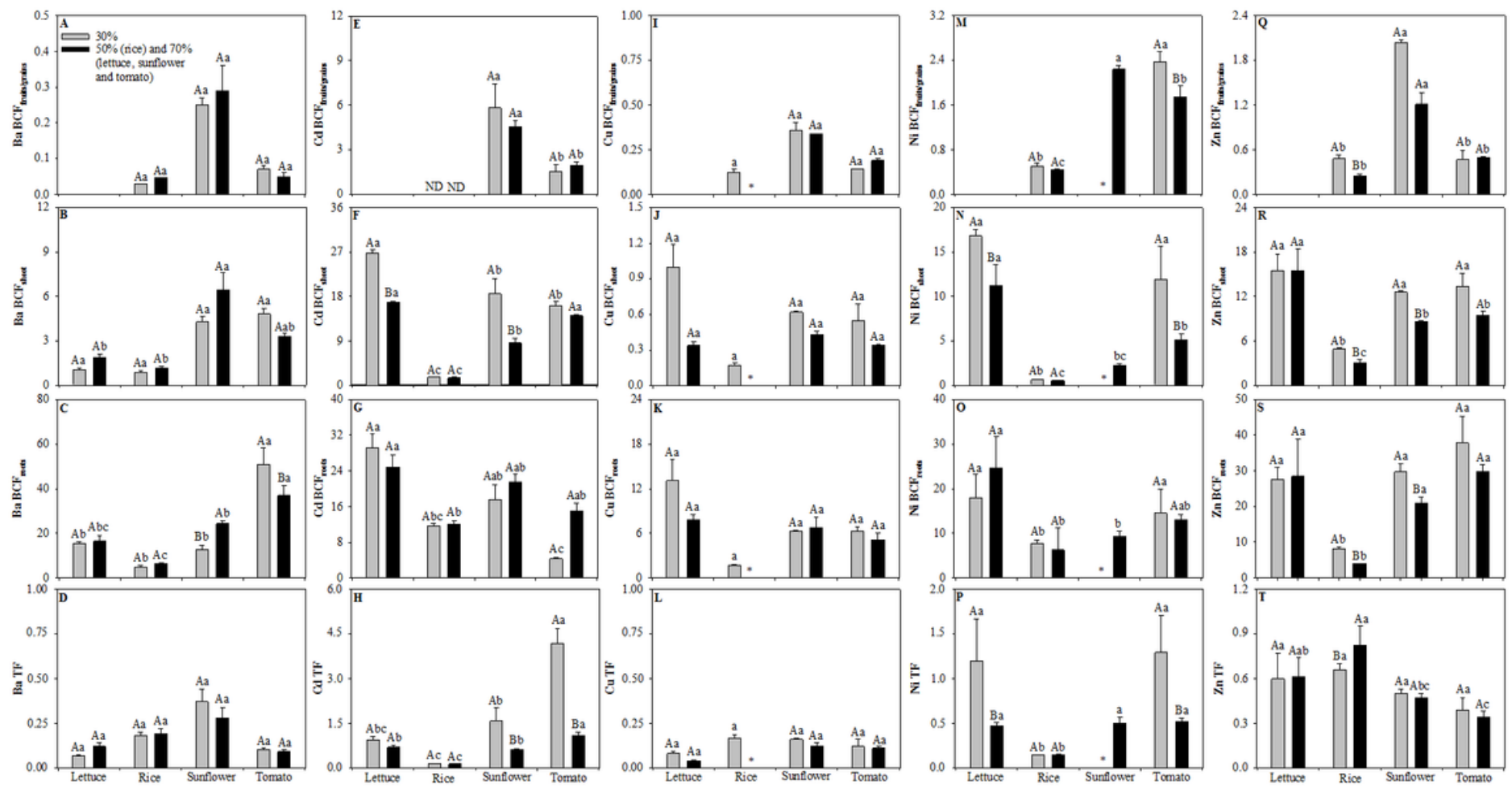

\section{Figure 4}

Bioconcentration factor (BCF) for Ba (A-C), Cd (E-G), Cu (I-K), Ni (M-O) and Zn (Q-S) in fruits or grains (A, E, I, M and Q), shoot (B, F, J, N and $R$ ) and roots $(C, G, K, O$ and $S$ ) and translocation factor (TF) for $\mathrm{Ba}(\mathrm{D}), \mathrm{Cd}(\mathrm{H}), \mathrm{Cu}(\mathrm{L}), \mathrm{Ni}(\mathrm{P})$ and $\mathrm{Zn}(\mathrm{T})$ in lettuce, rice, sunflower and tomato grown on $\mathrm{Ba}, \mathrm{Cd}, \mathrm{Cu}, \mathrm{Ni}$ or Zn-polluted Entisol under two soil base saturation (BS\%). Distinct upper case letters indicate difference between base saturation within each crop for each trace element and distinct lower case letters indicate difference between each trace element within each base saturation for each crop (Tukey test, $\mathrm{P} \leq 0.05$ ). Asterisks $(*)$ indicate treatment lost due to plant death. ND $=$ nondetermined 